\title{
Welcome to the Gray Zone: Shades of Honesty and Earnings Management
}

\author{
Pascale Lapointe-Antunes \\ Goodman School of Business \\ Brock University \\ plapointe@brocku.ca \\ Kevin Veenstra* \\ DeGroote School of Business \\ McMaster University \\ veenstk@mcmaster.ca \\ Kareen Brown \\ Goodman School of Business \\ Brock University \\ kbrown6@brocku.ca \\ Heather Li \\ Nanyang Business School \\ Nanyang Technological University \\ heatherli@ntu.edu.sg
}

* Corresponding Author. We gratefully acknowledge helpful comments from Hamza Warraich, Christine Weidman, conference participants at the CPA Manitoba Accounting Research Conference, the Inaugural Conference on Intelligent Information Retrieval in Accounting and Finance (CUHK, Shenzhen), the 2019 AAA Forensic Accounting Section Conference, the 2019 CAAA annual conference, the 2019 AAA Annual Meeting, the 2019 Conference on the Convergence of Financial and Managerial Accounting Research (CFMA) and seminar participants at McMaster University, the University of Waterloo and Carleton University. We acknowledge the financial support from the CPA/Brock Institute for International Issues in Accounting and the Social Sciences and Humanities Research Council (SSHRC). All errors are our own. 


\title{
Welcome to the Gray Zone: Shades of Honesty and Earnings Management
}

\begin{abstract}
We examine the influence of face-based judgments of CFO/CEO honesty on earnings management for the largest publicly traded companies in America. After controlling for incentives and opportunities to manage earnings, CFOs and CEOs perceived to be less honest engage in higher levels of both accruals and real earnings management. The beneficial impact of perceived honesty on earnings quality is most pronounced when both the CFO and the CEO are perceived to be honest. Findings are consistent with our conjecture that both the CFO and CEO independently contribute to a firm's reporting environment and Kahneman's (2003) findings that many aspects of person perception can be considered to be "intuitive".
\end{abstract}

JEL Classification: D22, D91, M12, M14, O51.

Keywords: Upper echelons theory, earnings management, visual cues. 


\section{WELCOME TO THE GRAY ZONE}

\section{INTRODUCTION}

This paper explores whether and how perceived CFO and CEO honesty is associated with a firm's propensity to engage in earnings management. Honesty in financial reporting is essential for stakeholders to be able to trust the information they receive and make appropriate judgments about the underlying performance of a company. Generally accepted accounting principles (GAAP) require the exercise of significant managerial discretion in preparing the financial statements. Discretionary accounting choices exist along a continuum (Amiram et al. 2018). On the one side is the use of reporting discretion to communicate private information that help investors assess economic performance and form rational expectations of future earnings prospects (Dechow and Skinner 2000). On the other side is financial reporting fraud (Amiram et al. 2018). We are interested in the significant gray zone that lies in between, where managerial discretion is used to mislead stakeholders or to influence contractual outcomes without violating GAAP (Healy and Wahlen 1999), making it difficult to distinguish between "acceptable" and "unacceptable" earnings management practices and to assess whether they are inherently unethical (Merchant and Rockness 1994; Kaplan 2001; Amiram et al. 2018).

When presented with seemingly identical incentives and opportunities, not all individuals choose to manage earnings (Amiram et al. 2018). Why? Relying on upper echelons theory, recent research focuses on the personality and characteristics of the individuals involved in making financial reporting decisions to answer this question (e.g. Bamber et al. 2010; Ge et al. 2011; Demerjian et al. 2013; Van Scotter and Roglio 2018; Buccholz et al. 2019). Upper echelon theory views organizational outcomes, such as earnings quality, as reflections of executives' personalized interpretation of the situation, which in turn depends on their experiences, values, and personalities (Hambrick and Mason 1984; Hambrick 2007). The ability of personal 


\section{WELCOME TO THE GRAY ZONE}

characteristics to explain organizational outcomes is directly proportional to managerial discretion: the more discretion managers have, the more their personal characteristics will be reflected in the decisions they make (Hambrick and Finkelstein 1987; Finkelstein and Hambrick 1990). Organizational outcomes are better explained by identifying the executive subgroups who are primarily responsible for a decision and using their collective personal characteristics to predict actions (Jackson 1992). Interfaces between members of the top management team (TMT) influence strategic decision-making and collective performance (Simsek et al. 2017, p. 283). The predictive value of upper echelons characteristics also depends on intra-TMT power. The more power an individual has, the more weight should be given to their characteristics when predicting strategic choices (Finkelstein 1992).

In their review of the accounting literature that draws on upper echelons theory, Plöckinger et al. (2016) identify the need for future research to develop and use directlymeasured psychological characteristics from established frameworks to obtain a more detailed and reliable assessment of the psychological processes that link executive characteristics to financial reporting choices. We take advantage of recent developments in the personality literature to answer their call. Specifically, we ask whether a novel measure, face-based judgments, for an emerging dimension of personality, honesty-humility, can be used to identify those CFOs and CEOs who are most likely to manage earnings. The CFO/CEO team is a natural research focus since they share primary responsibility for financial reporting decisions.

The five-factor model of personality, or Big Five, has dominated personality research since the early 1990s. The HEXACO inventory of personality traits, or Big Six model, developed by Ashton and Lee (2005) adds a sixth dimension to personality - honesty/humility. The HEXACO model implies that individual differences in honesty represent a core dimension of 


\section{WELCOME TO THE GRAY ZONE}

personality that exists beyond the five other trait dimensions (Ashton and Lee 2007). Hilbig and Zettler (2015) suggest it might be the "quintessential basic trait to account for individual differences in (un)ethical behavior". As such, the honesty/humility dimension of the Big Six model may provide important insights into the varying shades of CFO and CEO honesty and their association with earnings management behavior that have yet to be examined.

The study of CFO and CEO personality, however, presents significant measurement challenges, particularly for large-scale empirical studies. Top executives are generally reluctant to participate in scientific research, particularly when it involves psychological assessments using surveys and questionnaires. Existing research circumvents this issue by relying on externally observable demographic indicators as proxies for underlying psychological characteristics; or collecting primary data from student participants in small sample experimental settings (Hambrick and Mason 1984; Hambrick 2007; Plöckinger et al. 2016).

Research from trait theorists suggests face-based judgments could offer a way to measure honesty on a large-scale more directly. The face, often referred to as the window to the soul, is used to communicate intentions and emotions and is scrutinized by others during encounters (Porter et al. 2008). Inferences of trustworthiness are made almost instantaneously and they form the basis for judgments of honesty (Baker et al. 2016). Face-based judgments of trustworthiness tend to be more accurate predictors of behavior when the behavior observed is frequent and not blatantly criminal (Rule et al. 2013; Wilson and Rule 2017). Given that within-GAAP earnings management is common, but very rarely prosecuted on its own (Jones et al. 2008; Dechow et al. 2011), it should prove a good context for exploring the hypothesized accuracy of face-based judgments of CEO and CFO honesty. 


\section{WELCOME TO THE GRAY ZONE}

We download the photos of CFOs and CEOs from company websites, annual reports and Google Images for the S\&P 500 group of companies for the years 2011, 2012 and 2013. ${ }^{1}$ Raw honesty scores are obtained from Amazon Mechanical Turk (MTurk). For each photo, MTurk workers rate the perceived honesty by answering a series of 10 questions adapted from the HEXACO-PI-R self-report form (Lee and Ashton, 2018). The raw quantitative scores for each $\mathrm{CFO} / \mathrm{CEO}$ photo are then converted into a single perceived honesty measure that proxies for investor face-based judgments. We include unsigned (absolute) accrual-based and real earnings management measures in our empirical analyses. If investors (as proxied for by MTurk workers) are able to effectively form face-based judgments of CFO/CEO honesty-humility and if their initial judgment effectively relates to actual earnings management behavior, then we should observe a negative association between perceived CFO/CEO honesty and both accrual-based and real earnings management.

We first examine this association for the CFO and the CEO independently. We find that CFOs perceived to be less honest engage in more accruals-based and real earnings management. The association between CEO honesty and earnings management behavior is more tenuous, but stronger for CEOs in the top quartile for perceived honesty. Furthermore, perceived CFO and CEO honesty act as complements in explaining earnings management behavior. We then examine the association between perceived honesty and earnings management when the CFO and CEO of a company are both perceived to be more (less) honest. Results generally support the assertion that matching matters: the firm engages in less earnings management when both the CEO and the CFO are perceived to be more honest than when either one or both individuals are

\footnotetext{
${ }^{1}$ Our choice of these years avoids the potentially confounding effects of the 2007/2008 financial crisis. We limit our analyses to three years due to the extensive time and financial constraints of manually collecting and rating this large dataset of S\&P 500 firms.
} 


\section{WELCOME TO THE GRAY ZONE}

perceived to be less honest. Last, we consider the impact of CEO structural power and find that it moderates the association between perceived CEO honesty and earnings management.

Our paper contributes to the literature in several ways. First, in contrast with prior studies that focus on the extremes of personality (i.e., the Dark Triad which only affects a small percentage of the population) and unethical financial reporting behavior (i.e., financial statement fraud), we explore the varying shades of CFO and CEO honesty and their link with earnings management. Second, we show that face-based judgments of perceived honesty, a novel way to measure CFO and CEO personality, can be used in large-scale empirical studies to explore the pervasiveness of questionable financial reporting behavior. In so doing, we contribute to a better understanding of the psychological and social processes by which upper echelon characteristics translate into financial reporting and other strategic choices (e.g. Hambrick 2007; Wang et al. 2016; Plöckinger et al. 2016). Third, through the inclusion of both CEO and CFO characteristics, we address the question as to the importance of the CEO and the CFO in acts of earnings management. Consistent with recurring findings that one unethical individual can impact other individuals (Elias 2004, Pinto et al. 2008), we find that CFO personality moderates the relationship between CEO personality and earnings management propensity. Last, we contribute to the growing body of literature interested in the ability of the emerging honesty/humility personality factor to account for individual differences in ethical behavior.

The reminder of this paper is organized as follows. Section II discusses the related literature and develops the hypotheses. Section III describes the data and research design. Section IV presents the results of the empirical analysis and robustness checks. Section V concludes. 


\section{BACKGROUND AND HYPOTHESES}

\subsection{Earnings Management and Upper Echelons Theory}

Financial reporting is a key component of a firm's communication strategy with external stakeholders. Financial reporting choices can be complex and are of major significance to the entity since they impact its value and its ability to maintain or secure financing (IASB 2019). Past research largely relies on firm-level measures to explain earnings management behavior. Incentives to manipulate earnings include performance-based compensation (e.g. Healy 1985; Holthausen et al. 1995; Efendi et al. 2007), financing and leverage (e.g. Sweeney 1994; Dichev and Skinner 2002; Beatty and Weber 2003), operating losses (e.g. Burgstahler and Dichev 1997; Roychowdhury 2006; Burgstahler and Eames 2010) and strings of consecutive positive earnings (Dechow et al. 1996). Earnings management is more prevalent following the disclosure of internal control deficiencies (e.g. Ge and McVay 2005; Ashbaugh-Skaife et al. 2009; Chan et al. 2008) or as the quality of board and audit committee oversight decreases (Efendi et al. 2007; Bilal and Komal 2018).

Capital market and contracting motivations and organizational constraints are necessary, but not sufficient, conditions to consistently explain earnings management behavior (Amiram et al. 2018). Most discretionary accounting choices belong to the significant gray zone between signalling and opportunism and are neither completely ethically nor unethically acceptable (Amiram et al. 2018; Buccholz et al. 2019). In addition, prior research suggests an individual's ethical behavior is ultimately driven by their "personal" code of ethics (Al-Khatib et al. 2004; Beaudoin et al. 2015). Taken together, this suggests financial reporting choices cannot be detached from the individuals who make them, and individual predispositions are likely to be a significant determinant of the decision to engage in earnings management. 


\section{WELCOME TO THE GRAY ZONE}

Upper echelons theory has been used extensively to explain organizational outcomes and results generally confirm the influence of managerial characteristics on strategic decisions and firm performance (e.g. Nielsen 2010; Hiebl 2014; Wang et al. 2016) as well as financial reporting decisions (see Plöckinger et al. (2016) for a review of the literature). The majority of studies examine the influence of CEOs' and/or CFOs' demographic characteristics, including gender, education and experience. Some efforts have been made to measure behavioral and psychological characteristics indirectly. Most papers focus on CEO narcissism and overconfidence and use secondary observable data as proxies for behavioral and psychological characteristics. Narcissistic and overconfident CEOs are more likely to manage earnings, report less conservatively, are associated with more restatements, and are more likely to commit financial reporting fraud (Schrand and Zechman 2012; Ahmed and Duellman 2013; Hsieh et al. 2014; Olsen et al. 2014; Hribar and Yang 2016; Bucholz et al. 2019). Ham et al. (2017) find similar results for narcissistic CFOs. Murphy (2012) and Majors (2016) examine the association between Dark Triad traits, i.e. narcissism, Machiavellianism and psychopathy, and financial misreporting in experimental settings. ${ }^{2}$ They find that university student participants with higher scores on any of the three dimensions are more likely to engage in misconduct.

More closely related to our paper are the few studies that investigate the influence of executives' power and individual ethical predispositions on financial reporting outcomes. Gul and Leung (2004) and Cerbioni and Parbonetti (2007) show CEO power is negatively associated with voluntary corporate disclosures and intellectual capital disclosures in the annual report, respectively. Feng et al. (2011) find that CEOs have the power to pressure CFOs into manipulating financial statements. Larcker and Zakolyukina (2012) find that deceptive

\footnotetext{
${ }^{2}$ Paulhus and Williams (2002) were the first ones to coin these three constructs "Dark Triad". See Muris et al. (2017) for a review of the literature on the Dark Triad.
} 


\section{WELCOME TO THE GRAY ZONE}

executives exhibit more references to general knowledge, fewer non-extreme positive emotions, and fewer references to shareholder value. Patelli and Pedrini (2015) show that financial reporting aggressiveness is associated with a resolute, complex and non-engaging language. Biggerstaff et al. (2015) and Davidson et al. (2015) find that CEO unethical behavior, measured by stock option backdating and prior legal convictions, is positively associated with financial reporting fraud. Baker et al. (2019) find that powerful CFOs limit the ability of powerful CEOs to manage earnings via accruals and powerful CEOs limit the ability of powerful CFOs to engage in real earnings management.

Despite the progress made to date, much remains to be done to open the "black box" and better understand the psychological and social processes by which upper echelon characteristics translate into financial reporting and other strategic choices (e.g. Hambrick 2007; Wang et al. 2016; Plöckinger et al. 2016). Developing and using directly measured psychological characteristics is challenging, both conceptually and methodologically. The Dark Triad focuses on three sub-clinical personality traits that are at the extremes of normality in social functioning and therefore only affect a small percentage of the population (e.g. Coid et al. 2009; Babiak et al. 2010; Dhawan et al. 2010). ${ }^{3}$ Surveys and questionnaires provide primary data but limit sample size and introduce response and non-response biases. We suggest using honesty-humility, an emerging dimension of personality, measured with face-based judgments to address these conceptual and methodological challenges.

\subsection{Opening the Black Box}

\footnotetext{
${ }^{3}$ Subclinical narcissism has all the facets of Narcissistic Personality Disorder, a clinical psychopathology, but is less extreme. It is not immediately apparent and is often difficult to diagnose.
} 


\section{WELCOME TO THE GRAY ZONE}

\subsubsection{The Big 5 Personality Traits}

The role played by personality in determining individual patterns of thought and behavior is well-established in the psychology literature. Personality consists of stable individual patterns of thinking, feeling and behaving over time and across situations (e.g. Montag and Elhai 2019). While personality traits can change incrementally across the life course, the rank-order of personality traits relative to other individuals of the same age is generally consistent from early adulthood to old age (Roberts et al. 2000; Roberts et al. 2006; Ashton and Lee 2016).

The Big Five personality traits have been shown to be consistent across research methods and are genetically based, stable and cross-culture generalizable (e.g. Costa and McCrae 1988; McCrae and Costa 1997; Moberg 1999). However, existing research only provides some evidence of a relationship between ethical behavior and the five trait dimensions of personality. Agreeableness and conscientiousness have been shown to be positively associated with moral actions (Pohling et al. 2016), positively related to ethical leadership (Kalshoven et al. 2011), negatively associated with CEO involvement in fraud (Van Scotter and Roglio 2019), and negatively associated with the willingness to cheat on taxes, accept bribes in the course of jury duty and steal property (Seema and Parboteeah 2019).

\subsubsection{The HEXACO Model of Personality}

The six-factor HEXACO model has become a well-recognized alternative to the Big Five model in recent years (Moshagen et al. 2018). It reconfigures the Big Five "Emotional Stability" and "Agreeableness" factors into "Emotionality" and "Agreeableness" and introduces a sixth factor, "Honesty-Humility" (Ashton et al. 2004). ${ }^{4}$ The six personality factors can be found in all

\footnotetext{
${ }^{4}$ The sixth dimension, as per personal discussions with Michael Ashton, resulted from lexical studies of personality structure in 12 languages. In layman's terms, in a lexical study, the researcher goes to the dictionary for a given language, finds the descriptive personality adjectives for that language, and performs a factor analysis to identify a
} 


\section{WELCOME TO THE GRAY ZONE}

languages and cultures (Ashton and Lee, 2010; Ashton et al., 2004). Honesty-Humility represents "the tendency to be fair and genuine in dealing with others even when one might exploit without suffering retaliation" (Ashton and Lee 2007, p. 156). It is defined by facets that assess the "tendency to exploit others by subtle manipulation (low sincerity) or by more direct fraud (low fairness) and to feel entitled and motivated to profit by exploiting others (low modesty and low greed-avoidance)" (Ashton and Lee 2007, p. 158). As such, it is expected to be the "quintessential basic trait to account for individual differences in (un)ethical behavior" (Hilbig and Zettler 2015). ${ }^{5}$

The Honesty-Humility factor accounts for differences in several behaviors beyond the classic Big Five, including workplace delinquency (Lee et al. 2005), likelihood to sexually harass (Lee et al. 2013), sexual quid pro quos (Ashton and Lee 2008), integrity and counterproductive work behavior (Zettler and Hilbig 2010) and sustainable behavior in the workplace (Marcus and Roy 2019). Closely related to our research, Hilbig and Zettler (2015) find that Honesty-Humility is the only consistent predictor of variance in dishonest behavior across different cheating paradigms and incentive structures.

Honesty-Humility facets overlap conceptually and empirically with the Dark Triad components and the individual Dark Triad subscales (e.g. Lee et al. 2013; Jones and Paulhus 2017; Muris et al. 2017). However, the effect sizes of Honesty-Humility in predicting ethical decision-making are significantly larger than those of Machiavellianism (Kibeom et al. 2008). As such, honesty-humility measures should be preferred to the Dark Triad measures because

few major dimensions that underlie the multitude of personality traits. The researcher then assigns a name to each of these factors.

${ }^{5}$ Honesty/humility shows an upward trend of about one standard deviation unit between the ages of 18 to 60 . However, the rank order of this personality trait is constant. Developmental changes are likely to be the main explanation for this age trend (Lee et al. 2016). 


\section{WELCOME TO THE GRAY ZONE}

they allow for the study of inter-individual differences across the full continuum of this personality construct rather than exclusively at the extremes. This is particularly important given the fact that most people are willing to cheat a little as long as the transgressions are sufficiently minor to maintain a positive self-view (e.g. Hilbig and Hessler 2013). For example, Chung and Hsu (2017) conduct a multi-period economic-choice experiment asking participants to submit managerial reports in which they can overstate product costs to increase personal payoffs and are not subject to monitoring, auditing or reputation effects. While $21 \%$ of participants are completely dishonest and $11 \%$ are completely honest, the vast majority (68\%) are found to be partially honest.

\subsubsection{Face-Based Judgments}

Personality constructs are typically measured using self- or observer reports. Self(observer) reports are obtained, for example, by asking targets (informants) to answer personality questionnaires. Personality psychology research relies on the agreement between self-reports and observer reports from well-acquainted informants who have observed the target engage in many different behaviors in their everyday interactions to validate the factor structure of a personality inventory (Connelly and Ones 2010). Kibeom et al. (2008), Ashton and Lee (2009), Ashton and Lee (2010) and more recently Moshagen et al. (2018) find strong correlations between self and observer ratings for the six personality scales of the HEXACO model, supporting its validity.

The accuracy of observer reports from strangers (zero acquaintance studies) has received considerable attention in social psychology research in the past three decades. Zero-acquaintance designs combine thin-slice assessments of dynamic behavior or observation of static still frames with psychometric scales such as personality inventories. Thin slices are less than five minutes long and can be sampled from any available channel of communication, including the face, 


\section{WELCOME TO THE GRAY ZONE}

speech and transcripts (Ambady et al. 2000; Murphy 2005). Static observations are commonly based on face-based judgments of photographs. Observer reports are considered accurate if they predict self-reports (self-other accuracy), judgment from other observers (interrater reliability) and behaviors and outcomes (validity) (Funder and West 1993).

Stranger ratings have been shown to be surprisingly consistent with self-ratings (e.g. Paunonen 1991; Borkenau and Liebler 1993; Shevlin et al. 2002; Vazire 2006; Carney et al. 2007; Balsis et al. 2015). Dynamic stimulus is only marginally more accurate than static stimulus. For example, Borkenau and Liebler (1992) collect short samples of behavior from 100 participants and have four separate groups of judges (six per group) rate all 100 targets on the Big 5 personality traits using a still photo, a video recording without audio, the audio recording without video, and the video recording with audio, respectively. They find that a still photograph is sufficient to provide moderate correlations on the Big 5 traits. According to Connelly and Ones (2010), the information available to strangers is limited so the differences in stimulus do not substantially impact self-other correlations. Alternatively, external influences may "simultaneously lead to the development of certain personality attributes and a facial appearance that is stereotypically associated with those attributes" (Penton-Voak et al. 2006). In other words, "it may be the case that people either consciously or unconsciously manipulate their facial poses in very subtle ways that project their internal states." (Berry and Wero 1993).

Personality trait perception appears to be more accurate for highly visible and nonevaluative traits such as extraversion and for male than female faces (Borkenau and Liebler 1992; Connelly and Ones 2010). Hall et al. (2008) find that the average accuracy for the Big 5 trait judgments based on a dynamic stimulus is +0.23 , ranging from +0.12 for agreeableness to +0.40 for extraversion. Penton-Voak et al. (2006) use photos of 294 individuals who also 


\section{WELCOME TO THE GRAY ZONE}

completed a Big 5 self-report personality questionnaire. They find a significant relationship between self-reported and perceived extraversion (both male and female faces) and self-reported and perceived emotional stability/openness to experience (male faces only). ${ }^{6}$

It is essential to obtain ratings from a sufficient number of unacquainted informants to reach a desirable level of interrater reliability. Ratings from a single observer provide an idiosyncratic perspective from which to assess the target's personality and are subject to ratererror factors unique to the particular time at which the rating is collected, for example. The aggregation of responses from multiple raters into a composite rating attenuates the impact of rater idiosyncrasies. Consensus between multiple raters suggests the personality trait measured is meaningfully expressed through the chosen stimuli, the raters have been able to perceive the trait from the stimuli and to measure the trait with relatively little rater-specific error. Combining ratings from nine or ten unacquainted raters is sufficient to reach a +0.80 level of interrater reliability for most personality traits (Connelly and Ones 2010).

Although scarce, prior research suggests face-based judgments by strangers can reliably predict behavior, supporting their validity. Berry (1990) find that individuals who are judged to look warm in a neutral-expression photograph are consistently described as warm by their classmates after nine weeks of acquaintance. Similar results are found for social power and honesty. Rule and Ambady (2008), using cropped CEO head shot photographs, find that stranger ratings of CEO perceived leadership are strongly related to company profits, even when the photos were taken before the individuals became business leaders.

\footnotetext{
${ }^{6}$ Testosterone levels are correlated with ratings of masculinity and expressive behaviors such as smiling, leading to accurate perception of traits such as extraversion and agreeableness for males (Penton-Voak and Chen 2004; Dabbs 1997). A self-fulfilling prophecy may also be at play, whereby males with facial features that elicit attributes of agreeableness may be treated as more trustworthy and thereby develop more agreeable personality characteristics (Zebrowitz et al. 1996; Zebrowitz and Collins 1997).
} 


\section{WELCOME TO THE GRAY ZONE}

A number of papers related to our research examine face-based judgments of trustworthiness and honesty. Inferences of trustworthiness are formed unconsciously, occur within 38 milliseconds, are virtually unchanged as exposure increases, and form the basis for judgments of honesty (Evans 2008; Baker et al. 2016; Todorov and Porter 2014). Facial appearance, based on unchanging aspects of facial structure, as displayed in photos, is as successful as dynamic emotional expression in helping the observer form an impression of trustworthiness (Baker et al. 2016; Porter et al. 2008). In fact, of all the personality traits, including attractiveness, trustworthiness judgments show the highest correlation between judgments made after a 100-ms exposure and judgments made in the absence of time constraints (Willis and Todorov 2006).

Perceptions of trustworthiness matter because they can influence various important decisions, including investment, lending, and valuation decisions and initial audit fees (e.g. Duarte et al. 2012; Tingley 2014; Blankespoor et al. 2017). In the context of financial reporting, Gomulya et al. (2017) find that U.S. restatement firms are more likely to hire trustworthy looking successor CEOs. These successor CEOs, in turn, obtain more positive reactions by investment analysts and the media than their less trustworthy looking peers. Hsieh et al. (2019) find that auditors charge $5.6 \%$ less audit fees to firms with trustworthy-looking CFOs in initial audit engagements.

Whether initial judgments of trustworthiness reliably predict deceptive behavior appears to be contingent on the deceptive behavior being characterized (Wilson and Rule 2017). For example, Bond et al. (1994) find that people whose faces are thought to look dishonest are more likely to volunteer for an experiment that wold involve lying to their peers than are people with honest-looking faces. Face-based judgments of trustworthiness are shown to accurately 


\section{WELCOME TO THE GRAY ZONE}

differentiate between faces of America's most wanted criminals and recipients of great honors (e.g. Nobel prizes) (Porter et al. 2008), to differentiate between violent and nonviolent criminals (Stillman et al. 2010) and to determine whether one is willing to cheat by entering extra ballots in a lottery (Geniole et al. 2014). However, they do not appear to differentiate between military criminals and heroes and undergraduate students cheating on a test (Rule et al. 2013). According to Slepian and Ames (2016), these mixed results could be due to the choice of "single, relatively extreme and heterogeneous behaviors" (p.283). These authors find that ratings of trustworthiness most accurately predict social and homogeneous behaviors.

Research that examines the potential value of zero-acquaintance observer reports to assess trustworthiness in organizational contexts is scarce. Overall, the literature suggests the accuracy of stranger ratings depends on the instrument used to measure perceived trustworthiness and the actual behavior being examined. Kibeom et al. (2008) find strong correlations between observer-reports of Honesty-Humility and ethical decision-making. They call for more research on the use of observer reports to explain organizational outcomes. We answer their call by examining whether observer reports of Honesty-Humility can be used to explain earnings management behavior.

\subsection{Research Hypotheses}

Our research hypotheses are built around the tenants of upper echelons theory combined with findings on earnings management, the Honesty-Humility dimension of personality, and face-based judgments of personality. The CFO and CEO share primary responsibility for financial reporting decisions within the TMT and therefore exercise individual and joint influence on the financial reporting process. Consistent with the concepts of behavioral integration and strategic interfaces, we focus on their personalities as determinants of earnings 


\section{WELCOME TO THE GRAY ZONE}

management behavior, first individually and then in combination. We also examine the moderating effect of CEO power on the relative influence of the CEO.

Opportunistic earnings management is prevalent. Public company CFOs, surveyed by Dichev et al. (2013), estimate that $20 \%$ of firms manage earnings in any given period, by as much as $10 \%$ of reported EPS, in an effort to influence stock price as a result of internal and external pressure to meet earnings benchmarks and to protect their compensation and reputation. However, Coram et al. (2017) show that ethical considerations are more important than selfinterest when CFOs and CEOs decide whether to manage earnings. According to Merchant and Rockness (1994), individuals base their judgment of ethicality on the timing, size and type of earnings management activities. Coram et al. (2016) show it is also largely driven by their perception that earnings management is lying, representing $31 \%$ of the explanatory power of ethics in CFOs' and CEOs' overall decision to manage earnings and $71 \%$ of the explanatory power of ethics in their decision about whether to use accruals or real earnings management.

The CFO and CEO have large incentives and many opportunities to manage earnings since a large portion of their compensation depends on the company's financial performance, they collectively possess significant proprietary information about the firm's financial position, and they can override internal controls. Their attitude towards the importance of accuracy and completeness of financial information released by the company sets the "tone at the top" for ethical financial reporting behavior. Consistent with the literature on the association between ethical decision-making and the Honesty-Humility dimension of personality, we expect CFOs and CEOs who are high on this dimension to be more likely to perceive earnings management as lying, and consequently to engage in less earnings management. Earnings management closely aligns with the definition of Honesty-Humility in that it involves CFOs and CEOs exploiting 


\section{WELCOME TO THE GRAY ZONE}

financial statement users (others) to their personal benefit by subtle manipulation of the meaning of GAAP as a result of personal or contractual incentives (motivations).

While public companies use multiple channels to disclose financial statement and related financial information to external users, including quarterly and annual mandatory filings, management forecasts of earnings, press releases, and conference calls (Healy and Palepu 2001), the annual report is often the only exposure to the CFO and CEO for the average investor (e.g. Brown et al. 2019). Prior work shows perception is more likely to predict behaviors that are useful to the observer (Zebrowitz and Collins 1997). Investors benefit from being able to differentiate between more and less honest CFOs and CEOs and identify those who are more likely to manage earnings because it allows them to make better investment decisions.

The $\mathrm{CFO}$ and $\mathrm{CEO}$ exercise independent influence on financial reporting through their respective positions. The CFO, typically in charge of budgeting, internal controls, and preparing financial reports, assumes ultimate responsibility for the quality of financial reporting (Gore et al. 2008; Feng et al. 2011; Baker et al. 2019). As the highest-ranking individual in the organization, the CEO is accountable to the board of directors for the current and future performance of the firm (Feng et al. 2011; Baker et al. 2019). To the extent unacquainted observers can effectively form face-based judgments of CFO/CEO honesty-humility that relate to actual earnings management behavior, perceived CFO and CEO honesty will individually explain earnings management behavior and complement each other in doing so. This leads to our first two research hypotheses.

\section{$H_{1 a}:$ Face-based judgments for perceived CFO honesty are negatively associated with earnings management.}




\section{WELCOME TO THE GRAY ZONE}

$H_{1 b}$ : Face-based judgments for perceived CEO honesty are negatively associated with earnings management.

$\mathrm{H}_{2}$ : Face-based judgments for perceived $\mathrm{CFO}$ and CEO honesty are complements in explaining earnings management.

The CFO and CEO exercise joint influence on financial reporting and other financialrelated business decisions. The professional relationship between the CEO and the CFO is increasingly considered the most important one in the TMT. Practitioners' surveys show that the role of the CFO has evolved considerably over time from reporting the financial results to becoming a strategic partner and trusted advisor to the CEO in managing the business (e.g. Russell Reynolds 2015). During the financial reporting process, the CFO facilitates the transfer of financial information to the CEO while the CEO provides policy guidance and support to the CFO (e.g. Hsieh et al. 2018). The two executives explicitly assume joint responsibility for the accuracy and completeness of financial information released by the company since they are legally required to separately certify that the financial statements included in quarterly and annual filings fairly present, in all material respects, the operations and financial condition of the company. A strategic interface between the two executives is created as their activities and attributes come into contact (Simsek et al. 2017).

Strategic leaders vary their behaviors on the basis of the traits of other leaders as a result of strategic interfaces (Simsek et al. 2017). The CFO and CEO must have a strong relationship to drive growth and maximize overall performance (CFO Selections Team 2017; Korn Ferry 2017). A poor relationship with the CEO is the number one reason a majority of CFOs would voluntarily leave their position and the top reason a company would look to replace their CFO (Korn Ferry 2017). Mutual trust is absolutely essential to build a strong relationship between the 


\section{WELCOME TO THE GRAY ZONE}

CFO and CEO and honesty is by far the most important personality trait on which trust is built (Prottas 2013; CEO Magazine 2016; Russell Reynolds 2015). While individuals who work closely with others that possess similar personality traits are more likely to achieve consensus (Bahns et al. 2017), this creates the risk of false consensus bias when they collectively decide to engage in negative actions or display negative behavior. Companies, for example, are more likely to engage in tax-avoidance activities when both their CEO and CFO are overconfident as they reach false consensus that it is the best course of action (Hsieh et al. 2018).

Taken together, the literature on strategic interfaces and group consensus suggests CFOs and CEOs with similar levels of honesty are more likely to have a strong relationship and to agree on whether to manage earnings opportunistically. To the extent unacquainted observers can effectively form face-based judgments of CFO/CEO honesty-humility that relate to actual earnings management behavior, CFOs and CEOs who are both perceived to be more (less) honest should reach a consensus to engage in less (more) earnings management. This leads to our third hypothesis.

$H_{3}:$ The association between face-based judgments for perceived honesty and earnings management is more pronounced when both the CFO and CEO are perceived to be more (less) honest.

The relative influence of the $\mathrm{CEO}$ on the financial reporting process largely depends on their power. More powerful CEOs can impose their will on their $\mathrm{CFO}$ and exercise more influence on the financial reporting process than their less powerful counterparts (Adams et al. 2005). The negative consequences of CEO structural power on financial reporting as a result of compensation and other economic incentives are well-documented in the literature (e.g. Feng et al. 2011; Cormier et al. 2016; Baker et al. 2019). As the CFO's superior, the CEO can influence 


\section{WELCOME TO THE GRAY ZONE}

their compensation, career opportunities, and decide to replace them if they don't comply with their demands (e.g. Feng et al. 2011; Baker et al. 2019). The CEO also derives structural power from his/her position as Chair of the board. Graham et al. (2019) show that the board becomes less independent as the CEO becomes more powerful. To the extent ethical considerations are more important determinants of the decision to manage earnings than economic incentives, structural power should also moderate the association between perceived CEO honesty and earnings management. This leads to our fourth research hypothesis.

$H_{4}:$ The association between face-based judgments for perceived CEO honesty and earnings management is moderated by CEO structural power.

\section{SAMPLE SELECTION AND VARIABLES}

\subsection{Sample and Data}

We obtain the list of companies included in the S\&P 500 index for the years 2011, 2012 and 2013. Due to data availability issues for a number of CEOs and CFOs, our sample is restricted to a total of 950 firm-year observations. We download photographs of all CEOs and CFOs from their respective company websites as well as from historical annual reports and Google Images when required. Face-based judgments of CFO and CEO honesty are assessed using ratings obtained from Amazon Mechanical Turk workers. Earnings management proxies are calculated using Compustat data, executive compensation data is obtained from Execucomp and internal control deficiency/audit fee data is obtained from Audit Analytics. Governance data is obtained from BoardEx. All variables are winsorized at $1 \%$ and $99 \%$.

\subsection{Perceived Honesty}

Raw honesty scores are obtained from Amazon Mechanical Turk (MTurk), a crowdsourcing Internet marketplace that enables individuals and employers (known as 


\section{WELCOME TO THE GRAY ZONE}

Requesters) to coordinate the use of human intelligence to perform tasks. Employers post jobs known as HITs (Human Intelligence Tasks) and workers (called Providers or more colloquially Turkers) can then select jobs and complete tasks for a monetary payment set by the Employer. MTurk workers rate the perceived CFO/CEO honesty by answering a series of 10 questions adapted from the HEXACO-PI-R observer form (see Appendix B) for each photo. ${ }^{7}$ For each question, the worker selects one of five options as follows: 1 - strongly disagree; 2 - disagree; 3 - neutral; 4 - agree; and 5 - strongly agree. To ensure accuracy, only Turk workers with a HIT (i.e. job) approval rating greater than or equal to 95\% and at least 100 approved HITs are used to rate the photographs. Each photo is rated, on average, 18 times to maximize interrater reliability.

The raw quantitative scores for each $\mathrm{CEO} / \mathrm{CFO}$ photo are then converted into a single perceived honesty measure. The actual number of ratings varies slightly from photo to photo because a random number generator is used to select photos for each rater. First, the mean of a rater's 10 scores for a given photo is calculated, taking into consideration those six questions which are reverse coded (see Appendix B for details). The mean score is increasing in perceived honesty, with higher (lower) scores representing higher (lower) perceived honesty. Next, the scores for each rater are analyzed to assess those raters who are unreliable. ${ }^{8}$ The scores for the reliable raters are then used to calculate the mean honesty score for each CEO/CFO photo.

\footnotetext{
${ }^{7}$ The form is available at http://hexaco.org/hexaco-inventory (Lee and Ashton, 2018).

${ }^{8}$ To control for rating quality, we only include a rater's scores in our sample if their ratings are of consistent quality. More specifically, we proxy for quality in two ways: (1) the standard deviation of mean scores for a given rater is at least 0.3 ; and (2) the average standard deviation of responses to the 10 honesty questions for a given rater is less than 1.1. Both of these criteria must be met for the rater's ratings to be included in our analysis. These cutoffs, though somewhat arbitrary, seem reasonable based on our review of the raw data.
} 


\section{WELCOME TO THE GRAY ZONE}

Finally, the variable is normalized (between 0 and 1) to facilitate the interpretation of regression coefficients. ${ }^{9}$ We refer to this variable as the normalized perceived honesty score (HONESTY).

Prior research suggests emotional expression affects inferences of personality attributes, with happiness increasing attributions of trustworthiness and attractiveness and anger/disgust decreasing these perceived attributes. However, Sutherland et al. (2017) find that the correlation between trustworthiness facial ratings for happy versus neutral emotions is +0.71 . The facial expression for our photos is either smiling or neutral, with little variation. As such, we are not concerned about the impact of emotional expressions introducing noise into our honesty proxy. ${ }^{10}$

\subsection{Earnings Management}

We include both accrual-based and real earnings management measures in our empirical analyses, as prior research shows a shift in preference from accruals-based to real earnings management in the post-SOX period to avoid the significant penalties imposed on CFOs and CEOs caught in engaging in accruals-based earnings management (e.g. Cohen et al. 2010; Bartov and Cohen 2009; Baker et al. 2019). We use unsigned (absolute) values for both discretionary and real earnings management measures in all of our analyses. While firms typically engage in earnings management to inflate reported earnings, the possibility also exists for firms to use earnings management techniques to decrease reported earnings i.e. "big bath" accounting, income smoothing. Although firms can strategically time debits and credits, as well as real

\footnotetext{
${ }^{9}$ Some researchers standardize the individual scores by subtracting the mean and dividing by the coder's standard deviation. We do not adopt this method because it could potentially reward "irresponsible" judges that predominantly assign the average rating and penalize those that followed instructions and used the entire scale.

${ }^{10}$ In fact, differences in emotional expressions across individuals may actually strengthen the validity of our proxy. As noted by Hehman et al. (2015), "while dynamic emotional resemblances may vary across multiple instances of a (given) target, in specific contexts they may exhibit a chronic tendency that conveys accurate information. For instance, although smiling is a dynamic cue, the frequency of a subtle smile might be diagnostic of intentions." During our photo collection process, we collect two to three photos for each executive. For each executive, we use the photo which is of the highest quality and is in a business context. Based on our qualitative assessment of a sample of these photos, we conjecture that subtle cues i.e. smirking; are consistent across photos for a given individual.
} 


\section{WELCOME TO THE GRAY ZONE}

business activities, in the short-term, accruals must reverse in future periods and a company must increase their levels of investment in the future to stay viable. In addition, ethical judgments of earnings management do not differ based on the direction of the effect on earnings (Merchant and Rockness 1994). We expect more honest CFOs and CEOs to engage in less earnings management, whether income-increasing or income-decreasing.

Accruals management - We first use the modified Jones model (Dechow et al. 1995) matched by performance (Kothari et al. 2005) to estimate normal accruals. Second, we use the Dechow and Dichev (2002) model to estimate normal working capital accruals. Formula details are provided in Appendix A. ABACC and DICHEV denote the absolute value of the estimated residuals from the industry-year regressions (with at least 15 observations) using the modified Jones model and Dechow and Dichev model, respectively. Higher values of ABACC and DICHEV indicate more accruals-based earnings management.

Real earnings management - Consistent with prior research (e.g. Roychowdhury, 2006; Cohen and Zarowin, 2010; Zang, 2012), we examine three methods of manipulating real activities: 1) accelerating the timing of sales and/or generating additional unsustainable sales to increase reported earnings $(A B C F O) ; 2)$ reducing discretionary expenditures to increase reported earnings $(A B E X P)$; and 3) overproducing or increasing production to report lower COGS and higher earnings (ABPROD). Formula details are provided in Appendix A. ABCFO, ABEXP and $A B P R O D$ denote the absolute value of the estimated residuals from the industry-year regressions (with at least 15 observations) for the Roychowdhury models. Following Cohen and Zarowin (2010) and Zang (2012), we aggregate the three individual measures into two proxies. REM1 is the sum of $A B E X P$ and $A B P R O D . R E M 2$ is the sum of $A B C F O$ and $A B E X P$. Higher values of REM1 and REM2 indicate more real activities manipulation. 


\section{WELCOME TO THE GRAY ZONE}

\subsection{Model}

We use the following OLS regression model to examine the association between perceived honesty and earnings management. Robust standard errors are clustered by financial year.

$$
\begin{aligned}
& E M_{i, t}=\operatorname{HONESTY}_{i, t}+\operatorname{STOCKCOMP}_{i, t}+\text { BONUS }_{i, t}+\operatorname{LOSS}_{i, t}+\operatorname{LEVERAGE}_{i, t} \\
& + \text { SECTION302 }_{i, t}+\text { PERCAUDITFEES }{ }_{i, t}+\operatorname{SIZE}_{i, t}+\text { MTB }_{i, t}+\text { ROA }_{i} \\
& +G E N D E R_{i, t}+Y E A R+\varepsilon_{i, t}
\end{aligned}
$$

Model (1) is first estimated for CFOs and CEOs independently. EM is one of two measures for accruals management and two measures for real earnings management. HONESTY, STOCKCOMP, BONUS and GENDER are CFO- and CEO-specific measures. HONESTY is first included in the model as a continuous measure. To examine whether the association between perceived honesty and earnings management is more pronounced in the extremes, we replace the continuous measure with indicator variables for perceived honesty scores in the top (TOPQ) and bottom $(B O T T O M Q)$ quartiles and repeat the analyses. TOPQ $(B O T T O M Q)$ is equal to 1 if HONESTY is in the top (bottom) quartile for sample CFOs (CEOs), 0 otherwise. Consistent with $\mathrm{H}_{1}$, we expect coefficients for $H O N E S T Y$ and $T O P Q$ to be negative and significant, and the coefficient for BOTTOMQ to be positive and significant. We then include both CFO HONESTY and CEO HONESTY in Model (1) to determine whether perceived CFO and CEO honesty contribute independently to a firm's propensity to manage earnings. We repeat the analysis using indicator variables for perceived honesty scores in the top and bottom quartiles. Consistent with $\mathrm{H}_{2}$, we expect the coefficients to retain their individual significance.

We then examine the interaction between $\mathrm{CFO}$ and CEO perceived honesty and earnings management behavior. STOCKCOMP and BONUS are replaced with the simple average of CFO 
WELCOME TO THE GRAY ZONE

and CEO STOCKCOMP and BONUS. Next, we add an interaction term between CFO HONESTY and CEO HONESTY to examine the association between perceived honesty and earnings management when the $\mathrm{CFO}$ and the $\mathrm{CEO}$ for a company are both perceived to be more (less) honest. To examine whether these associations are more pronounced in the extremes, we replace the continuous measures with indicator variables for CFO and CEO perceived honesty scores that are in the bottom $(B O T T O M Q)$ and top $(T O P Q)$ quartiles and repeat the analyses. Last, we include indicator variables equal to 1 if both the CFO and CEO are in the top quartile $(T O P Q / T O P Q)$, or in the bottom quartile $(B O T T O M Q / B O T T O M Q), 0$ otherwise. Consistent with $\mathrm{H}_{3}$, we expect the interaction term between CFO HONESTY and CEO HONESTY to be negative and significant and the coefficient for TOPQ/TOPQ (BOTTOMQ/BOTTOMQ) to be negative (positive) and significant.

Last, we add an interaction term between CEO HONESTY and CEO power (CEOPOWER) to examine whether it moderates the association between perceived honesty and earnings management. CEOPOWER is an indicator variable equal to 1 if the CEO is also Chairman of the board of directors, and 0 otherwise (Cormier et al. 2016; Baker et al. 2019). Consistent with $\mathrm{H}_{4}$, we expect the coefficient for the interaction term between CEO HONESTY and CEOPOWER to be negative and significant and the coefficient for TOPQ*CEOPOWER (BOTTOMQ*CEOPOWER) to be negative (positive) and significant.

\subsection{Other Variables}

\subsubsection{Incentives and Opportunities to Manage Earnings}

CFOs and/or CEOs are expected to manage earnings if they have incentives and the opportunities to do so. Incentives to manage earnings exist when management is under pressure 


\section{WELCOME TO THE GRAY ZONE}

to achieve an earnings target and the consequences of missing the target are significant (e.g. CAS 240, CPA Canada, 2018). STOCKCOMP, BONUS, LOSS, and LEVERAGE proxy for incentives to manage earnings (see Appendix A for variable definitions). Consistent with prior research on the relationship between executive compensation and earnings management (e.g. Healy, 1985; Holthausen et al., 1995; Balsam, 1998; Bergstresser and Philippon, 2006) and incentives to avoid losses ((e.g. Burgstahler and Dichev, 1997; Roychowdhury, 2006; Burgstahler and Eames, 2010) and debt covenant violations (e.g. Sweeney, 1994; Dichev and Skinner, 2002; Beatty and Weber, 2003), we expect STOCKCOMP, BONUS, LOSS, and LEVERAGE to be positively associated with earnings management measures.

Upper management members are in a unique position to manage earnings because they have the ability to override controls that appear to be operating effectively (Zhang et al., 2008; Schrand and Zechman, 2012). The risk of management override of controls is present in all entities, albeit at different levels (CAS 240, CPA Canada, 2018). SECTION302 and PERCAUDITFEES proxy for opportunities to manage earnings (see Appendix A for variable definitions). The CFO and CEO are required to attest to their responsibility for accuracy and veracity of financial reports and disclose any deficiencies in internal control under SOX Section 302. Prior research shows increased levels of real earnings management and accruals management following the disclosure of internal control deficiencies (e.g. Ge and McVay, 2005; Ashbaugh-Skaife et al., 2009; Chan et al. 2008). As such, we expect a positive association between SECTION302 and all earnings management measures. The ability for management to override controls is constrained by auditors, among others. Irrespective of the assessed risk of management override, auditors are required to perform procedures to test for the appropriateness of journal entries recorded in the general ledger at the end of a reporting period, review 


\section{WELCOME TO THE GRAY ZONE}

accounting estimates for biases, and evaluate the plausibility of the business rationale for significant transactions outside of the normal course of business (CAS 240, CPA Canada, 2018). We expect auditors to exercise better oversight as the ratio of audit and audit-related fees increase. If such is the case, PERCAUDITFEES will be negatively associated with all earnings management measures.

\subsubsection{Control Variables}

Consistent with prior research, we control for systematic variations in earnings management measures with size, growth opportunities and profitability by including SIZE, MTB and $R O A$ in all regression models (see Appendix A for variable definitions). We also include an indicator variable equal to 1 if the $\mathrm{CFO}(\mathrm{CEO})$ is male, and 0 otherwise (GENDER). Prior research suggests female CFOs and CEOs are less likely to engage in earnings management (e.g. Liu et al. 2016; O’Neill et al. 2017). Hence, we expect GENDER to be positively associated with all earnings management measures.

\section{RESULTS}

\subsection{Descriptive Statistics}

Table 1 reports descriptive statistics for the variables included in the regression models. $77.76 \%(2.61 \%)$ of sample CFO and CEO compensation is equity-based (bonus-based) on average. This suggests strong incentives to manage earnings to protect equity-based compensation. $11.95 \%$ of sample firms disclose internal control deficiencies under SOX Section 302, supporting the existence of some opportunities for sample CFOs and CEOs to override controls to manage earnings. $87.95 \%$ of total audit fees are audit or audit-related on average. As such, we expect to see some evidence of auditor oversight acting as a constraint to real earnings 


\section{WELCOME TO THE GRAY ZONE}

and accruals management. Mean values for SIZE (9.8102), MTB (1.8295) and ROA (0.0620) suggest sample firms are large and profitable on average, consistent with their inclusion in the S\&P 500 Index.

Table 2 presents pairwise correlations between our variables of interest. Perceived CFO honesty is negatively and significantly correlated with most earnings management measures but perceived CEO honesty is not significantly correlated with any earnings management measures. There is a significant positive correlation between perceived CFO and CEO honesty. Consistent with expectations, earnings management measures are highly correlated with each another, supporting the existence of a concerted tendency to manage earnings both by managing accruals and real activities. Table 3 explores potential interactions between face-based judgments of perceived CFO and CEO honesty. The relationship between the classification factors is tested with a Chi-2 test. The Chi-2 statistic is significant at the $1 \%$ level, supporting the existence of CFO and CEO matching based on face-based judgments of honesty.

Table 4 compares mean values for accruals and real earnings management measures across subgroups of sample firms. Panels A and B partition the sample based on $25^{\text {th }}$ percentile and $75^{\text {th }}$ percentile values for CFOHONESTY (Panel A) and CEOHONESTY (Panel B). We test for differences between bottom quartile and top 3 quartiles, bottom 3 quartiles and top quartile, and bottom and top quartile. Panel C partitions the sample based on below/above $25^{\text {th }}$ percentile and $75^{\text {th }}$ percentiles values for the combined CFO (CEO) HONESTY scores. We expect mean values for the earnings management measures to be higher when perceived honesty is lower, individually or in combination. Individually, statistical significance is observed consistently for the CFO, but rarely for the CEO. When the CEO and CFO are analyzed in combination as noted 


\section{WELCOME TO THE GRAY ZONE}

in Panel C, statistical significance is observed consistently when comparing firms with the $\mathrm{CEO} / \mathrm{CFO}$ in the top quartile with those firms where both the $\mathrm{CEO} / \mathrm{CFO}$ are not in the top quartile.

\subsection{Multivariate Results}

Table 5 reports the OLS regression results of accruals management and real earnings management measures on perceived honesty, incentives and opportunities. Results for CFOs are presented in Panel A, results for CEOs are presented in Panel B and results for CFOs and CEOs (combined) are presented in Panel C. Coefficients for financial year indicator variables and the constant are not reported. Consistent with $\mathrm{H}_{1 \mathrm{a}}$, the coefficient for CFO HONESTY is negative and significant in all models. The coefficient for $T O P Q$ is negative and significant while the coefficient for BOTTOMQ is positive and significant for DICHEV, REM1 and REM2. The coefficient for CEO HONESTY is only statistically significant for REM1. TOPQ is negative and significant as predicted by $\mathrm{H}_{1 \mathrm{~b}}$ for $A B A C C$ and $R E M 2$ while $B O T T O M Q$ is positive and significant for DICHEV. Consistent with $\mathrm{H}_{2}$, the coefficients retain their significance when CFO and CEO HONESTY are both included in the model. Taken together, these results suggest a stronger association between perceived CFO honesty and earnings management measures than perceived CEO honesty and earnings management measures, with both measures contributing independently to the extent of earnings management. Results for incentives, opportunities and control variables are largely similar for all models and generally consistent with expectations. The coefficients for all other control variables vary in significance and direction.

Table 6 reports the OLS regression results of accruals and real earnings management measures on the interaction between perceived CFO and CEO honesty. Subsample sizes drawn 


\section{WELCOME TO THE GRAY ZONE}

from the full population are 64 for TOPQ/TOPQ and 74 for BOTTOMQ/BOTTOMQ. The first column presents results for the interaction between the continuous values of CFO and CEO HONESTY. The coefficient for $C F O+C E O+C F O * C E O$ is negative and significant as predicted for $A B A C C, R E M 1$ and REM2 and negative for DICHEV. The second column presents results relative to the reference subgroup of CFOs and CEOs where perceived honesty scores are both in the bottom three quartiles. The coefficients for $T O P Q / T O P Q$ are negative and statistically significant in all cases. Linear predictions reveal economically significant differences between the TOPQ/TOPQ group and the reference group, ceteris paribus. The third column presents results relative to the reference subgroup of CFOs and CEOs where perceived honesty scores are both in the top three quartiles. The coefficients for BOTTOMQ/BOTTOMQ are positive for all earnings management measures, but only significant for DICHEV and REM1. Linear predictions also reveal economically significant differences between the BOTTOMQ/BOTTOMQ group and the reference group, ceteris paribus. Taken together, these findings support lower (higher) levels of earnings management when perceived honesty scores for both the CFO and CEO are in the top (bottom) quartile. Consistent with $\mathrm{H}_{3}$, it suggests CFOs and CEOs with similar levels of honesty are more likely to agree on whether to manage earnings opportunistically.

Table 7 reports the OLS regression results of accruals and real earnings management measures on the interaction between perceived CEO honesty and CEO power. The first column presents results for the interaction between the continuous value of CEO HONESTY and CEOPOWER. The coefficient for HONESTY + POWER + HONESTY*POWER is negative as predicted for all earnings management measures but only significant for DICHEV. The second column presents results relative to the reference subgroup of CEOs, where perceived honesty 


\section{WELCOME TO THE GRAY ZONE}

scores are in the bottom three quartiles. The coefficients for CEOs with scores in the top quartile, who also act as Chairman of the board, are negative and statistically significant for DICHEV, REM1 and REM2 and negative for $A B A C C$. The third column presents results relative to the reference subgroup of CEOs where perceived honesty scores are in the top three quartiles. The coefficient for CEOs with scores in the bottom quartile, who also act as Chairman of the board, is only positive and significant for REM1. Linear predictions reveal economically significant differences between groups, ceteris paribus. Consistent with $\mathrm{H}_{4}$, this suggests $\mathrm{CEO}$ structural power moderates the association between perceived CEO honesty and earnings management, such that CEOs who are perceived to be more honest and hold a dual role engage in less earnings management.

\subsection{Robustness Checks}

\subsubsection{Self-Other Accuracy of Perceived Honesty}

Observer reports are considered accurate if they predict self-reports (self-other accuracy), judgment from other observers (interrater reliability) and behaviors and outcomes (validity) (Funder and West 1993). The observed link between face-based judgments of perceived honesty and tendency for earnings management is potentially contentious. ${ }^{11}$ Because we cannot assess the self-other accuracy of HONESTY using sample CFOs and CEOs, we ask a sample of 89 colleagues, friends and family members to complete the personality test (noted in Appendix C) and provide a personal photo. We use MTurk workers to rate the perceived honesty of each photo by answering the 10 questions noted in Appendix B. On average, each photo is rated by 35

11 Berry and Wero (1993) provide an excellent summary of this theoretical issue, including discussion of physiognomy which fell into disrepute in the early 1900s because its assertions about the relationship between personality and physical appearance were not based on scientific observation. 


\section{WELCOME TO THE GRAY ZONE}

individuals, with the average score taken as a proxy for perceived honesty. Next, the photo score is compared with the self-assessment score for each colleague/friend/family member. The correlation between third-party perception and personal self-assessment is statistically significant at +0.35 , which provides support for our assertion that perceived honesty is a meaningful and

validated proxy. ${ }^{12}$ In fact, this observed correlation may be understated due to the possibility of some individuals not answering the self-assessment questionnaire truthfully as a result of social desirability influences.

\subsubsection{Alternative Measure of Perceived Honesty}

Our proxy for perceived honesty is admittedly cumbersome, based on a series of 10 questions. To assess the significance of our results using a more direct approach, we get our MTurk workers to rate the photos based on a single question; namely: "how honest does the person look?" The correlation between these ratings and the ratings we used in our study is approximately +0.55 . However, the use of this measure results in significantly lower statistical significance in all of our models. As such, it appears that the HEXACO model is assessing honesty in a refined way that cannot be simply captured by a single question.

\subsubsection{Verbal Measure of Perceived Honesty}

Verbal communication is an important means by which executives communicate with stakeholders. For example, Bandiera et al. (2017) find that $85 \%$ of CEO time is spent on activities that involve communication, including speeches, phone calls, conference calls and meetings. DePaulo et al. (1983) find that liars provide both verbal and visual cues to their

\footnotetext{
12 In psychology/sociology research, correlations of between about -0.20 and +0.20 are considered small, correlations between -0.20 and -0.40 and between 0.20 and 0.40 are considered moderate in size, and correlations beyond -0.40 or beyond +0.40 are considered large (Ashton, 2013).
} 


\section{WELCOME TO THE GRAY ZONE}

deception. The lies of the highly motivated senders are less readily detected when only verbal cues are available but more readily detected in conditions that include both verbal and nonverbal cues. Vrij (2000) and Vrij et al. (2004) show that more accurate truth/lie decisions can be made when both speech content and non-verbal behavior are taken into account. Porter et al. (1995) and Porter et al. (1999) find that a combination of verbal and non-verbal cues assists in deception detection.

We explore the incremental explanatory power of verbal cues for honesty to assess whether face-based judgments provide complementary information about perceived $\mathrm{CFO}$ and CEO honesty. We extract both CEOs' and CFOs' speeches from quarterly earnings conference call transcripts obtained from Thomson Reuters StreetEvents (Hobson et al. 2012; Kimbrough 2005; Larcker and Zakolyukina 2012). Perceived honesty is measured as the percentage of “abstract" words used by CEOs and CFOs during these quarterly earnings conference calls, using both the prepared and the question and answer portions of each conference call. ${ }^{13}$ We take the average of the scores from the four quarterly conference calls as the proxy for honesty for each year. VERBAL is calculated as 1 - the normalized value of the score, such that higher positive values indicate more perceived honesty.

The correlation between CFO (CEO) HONESTY and CFO (CEO) VERBAL is $5.91 \%$ (10.57\%). The correlation between CFO VERBAL and CEO VERBAL is $33.86 \%$ and significant at the $1 \%$ level. This relatively high correlation indicates some level of coordination between the $\mathrm{CFO}$ and $\mathrm{CEO}$ as they prepare to discuss and answer questions related to quarterly earnings.

\footnotetext{
${ }^{13}$ The use of this specific list of abstract words (included in the General Inquirer Harvard IV-4 Dictionary) is consistent with the findings from Larcker and Zakolyukina (2012), who show that deceptive CEOs and CFOs use more references to "general knowledge". It is also consistent with results from Pan et al. (2018), who find that corporate leaders' use of "concrete" language is positively associated with investor reaction because concrete language can enhance the confidence investors have in them.
} 


\section{WELCOME TO THE GRAY ZONE}

Results from multivariate regressions (untabulated) support lower (higher) levels of earnings management when either visual or verbal cues for perceived CFO honesty are in the top (bottom) quartile. Results for CEOs support lower levels of earnings management when both visual and verbal cues for perceived honesty are in the top quartile, but limited evidence of higher levels of earnings management when either visual or verbal cues are in the bottom quartile. Taken together, this suggests visual and verbal cues for perceived CFO and CEO honesty act as complements in explaining financial reporting quality, consistent with prior literature that shows that looking at a combination of verbal and non-verbal cues assist in detecting deception (e.g. Porter et al. 1995; Porter et al. 2001).

\subsubsection{Signed Earnings Management Measures}

We rerun all regressions using signed values. On balance, we expect that CEOs and CFOs perceived to be less honest will engage in both accruals and real earnings management activities that increase reported net income. Results (untabulated) are broadly consistent with expectations. For the CFO, earnings management is decreasing in perceived honesty. For the $\mathrm{CEO}$, there is no significant relationship. Looking at $\mathrm{CEO} / \mathrm{CFO}$ interaction, there is a stronger negative relationship between perceived honesty and earnings management when the CEO and CFO are similar with respect to perceived honesty.

\subsubsection{Residuals as Dependent Variables}

Chen et al. (2018) find that the standard implementation of OLS to decompose a dependent variable into its predicted and residual components and use the residuals as the dependent variable in the second regression results in biased coefficients and standard errors that can lead to incorrect inferences. We use residuals as the dependent variable in the majority of our 


\section{WELCOME TO THE GRAY ZONE}

regressions. As such, our results are potentially sensitive to this critique. Consistent with Chen et al. (2018), we re-run all of our models, regressing the residual from the first-step regression on the combination of all second-stage and first-stage regressors to generate unbiased estimates of the coefficient of interest. Results (untabulated) for all accrual and real earnings management measures remain unchanged.

\subsubsection{Earnings Response Coefficients}

A long line of literature in accounting looks at the determinants of market reaction to unexpected accounting earnings. Earnings persistence, earnings quality, growth opportunities and similar investor expectations are positively associated with earnings response coefficients while beta and leverage show a negative association. In the context of perceived honesty, we conjecture that the market will react more strongly to earnings from those firms managed by CFOs and CEOs with higher perceived honesty because they engage in less earnings management and report more credible earnings. Consistent with prior literature, we explore the relationship between stock market response and unexpected earnings by regressing cumulative abnormal returns $(C A R)$ on standardized unexpected earnings $(S U E)$ with the regression coefficient on $S U E$ interpreted as the earnings response coefficient. $C A R$ is calculated as the abnormal stock returns (raw returns less expected returns using the CAPM model) for the period one day prior to one day subsequent to the earnings release $(-1,+1)$. SUE is calculated as the difference between the actual earnings and median analyst forecasts, divided by the standard deviation of unexpected earnings using median analyst forecasts over the past eight quarters.

Table 8 presents the regression results, where perceived honesty is partitioned above/below median. SUE* $<M E D I A N$ represents the average impact of $S U E$ for those 


\section{WELCOME TO THE GRAY ZONE}

observations where perceived honesty is below median. $S U E^{*}>=M E D I A N$ represents the average impact of SUE for those observations where perceived honesty is above or equal to median. Consistent with our expectations, the market reaction to unexpected earnings is stronger for almost all analyses when perceived honesty is above or equal to median.

\subsubsection{HEXACO and Big Five}

Plöckinger et al. (2016) suggest that future accounting research use the Big Five personality traits to explore the relationship between financial reporting choices and managerial idiosyncrasies. Consistent with Hrazdil et al. (2019), we use reverse coding and compute a risk tolerance index based on the sum of the Big 5 personality traits as follows: openness to experience $+(100-$ conscientiousness $)+$ extraversion $+(100-$ agreeableness $)+(100-$ emotionality) / 5. Each of the Big 5 personality traits is calculated in a similar manner to that noted above for honesty; the only difference being that for each Big 5 personality dimension, there is a series of 10 distinct questions which are adapted from the HEXACO-PI-R self-report form available at http://hexaco.org/hexaco-inventory (Lee and Ashton, 2018).

The Pearson correlation between this risk-taking index and honesty measures is -0.22 for CFOs and -0.23 for CEOs, consistent with more honest individuals taking less aggressive actions. We re-run all regressions from Table 5 using this new risk-taking measure. The risktaking measure is only significant in two instances; $D I C H E V$ for CFOs and $A B A C C$ for CEOs. Including both the risk-taking and perceived honesty measures in the regressions from Table 5 does not alter the sign or the significance of the results. Overall, this suggests the Big 5 personality dimensions have a minimal ability to help explain the propensity for a CEO and/or CFO to engage in accrual-based or real earnings management. 


\section{WELCOME TO THE GRAY ZONE}

\section{DISCUSSION AND CONCLUSION}

Using human rater scores to proxy for the perceived honesty of CFOs and CEOs at some of the largest public companies in America, and controlling for incentives and opportunities, we find that face-based judgments have significant power in explaining a company's propensity to engage in both real and accrual-based earnings management, individually and in combination. Our findings are broadly consistent with upper echelons theory; namely, that both the CFO and the CEO personality influence financial reporting, an important firm outcome.

Our findings suggest that $\mathrm{CFO}$ and $\mathrm{CEO}$ photos, readily available on the Internet, provide a quick and efficient way for stakeholders to assess their perceived honesty and the likelihood they will manage earnings opportunistically. Through the validation of our visual proxies using a sample of colleagues, friends, and family members, we are able to support our assertion that facial honesty scores are rooted in an individual's personality. We perform a number of additional analyses to ensure that our results are robust to a number of alternative model specifications. More specifically, we show that: (1) honesty/humility is distinct from the Big 5 personality traits; (2) our results are robust to the inclusion of verbal cues for perceived honesty; and (3) our results generalize to signed in addition to unsigned earnings management proxies.

Recent research shows that while CEO effectiveness includes such traits as humility, integrity, and creativity, creativity and integrity are negatively correlated in individuals (Beaussart et al. 2013). As such, the benefits of creativity may come at the cost of lower integrity. Future research could focus on the short- and long-term performance of the firms that CEOs and CFOs work for. Funder and Sneed (1993) find that that the validity in lay judgment by strangers may be the accurate weighting of numerous low-validity cues rather than the use of a small number of highly valid cues. Therefore, another interesting extension would be to focus on 


\section{WELCOME TO THE GRAY ZONE}

the sensitivity of the honesty/humility assessments to differences in facial expressions (i.e. anger, surprise, disgust, fear) (Naumann et al. 2009) as well as to vignettes (in place of still photographs) and non-facial cues such as clothing and hairstyle.

Given recent advances in machine learning and artificial intelligence, it would be interesting to see how and whether more sophisticated tools (i.e. supervised/unsupervised learning) provide insights over and beyond those obtained through more traditional methods. Given the plethora of previous research studies on textual analysis and the emerging research on facial appearance, it is safe to say there are more interesting topics yet to be explored. 
WELCOME TO THE GRAY ZONE

\section{References}

Adams, R., Almeida, H., and D. Ferreira. 2005. Powerful CEOs and Their Impact on Corporate Performance. Review of Financial Studies, 18 (4): 1403-1432.

Ahmed, A., and S. Duellman. 2013. Managerial Overconfidence and Accounting Conservatism. Journal of Accounting Research, 51(1): 1-30.

Al-Khatib, J., Rawwas, M., and S. Vitell. 2004. Organizational Ethics in Developing Countries: A Comparative Analysis. Journal of Business Ethics, 55(4): 307-320.

Ali, A., and W. Zhang. 2015. CEO Tenure and Earnings Management. Journal of Accounting and Economics, 59(1): 60-79.

Ambady, N., Bernieri, F., and J. Richeson. 2000. Towards a Histology of Social Behavior: Judgmental Accuracy from Thin-Slices of Behavioral Stream. Advances in Experimental Social Psychology, 32: 201-272.

Amiram, D., Z. Bozanic, J. Cox, Q. Dupont, J. Karpoff, and R. Sloan. 2018. Financial Reporting Fraud and Other Forms of Misconduct: A Multidisciplinary Review of the Literature. Review of Accounting Studies, 23(2): 732-783.

Amiram, D., S. Huang, and S. Rajgopal. 2018. Does Financial Reporting Misconduct Pay off Even When Discovered? Working paper.

Ashbaugh-Skaife, H., Collins, D., Kinney, W. and R. LaFond. 2009. The Effect of SOX Internal Control Deficiencies on Firm Risk and Cost of Equity. Journal of Accounting Research, 47(1): 1-43.

Ashton, M. 2013. Individual Differences and Personality. London, UK: Elsevier Inc.

Ashton, M., and K. Lee. 2005. Honesty-Humility, the Big Five, and the Five-Factor Model. Journal of Personality, 73: 1321-1353.

Ashton, M., and K. Lee. 2007. Empirical, Theoretical, and Practical Advantages of the HEXACO Model of Personality Structure. Personality and Social Psychology Review, 11(2): 150-166.

Ashton, M., and K. Lee. 2008. The Prediction of Honesty-Humility-Related Criteria by the HEXACO and Five-Factor Models of Personality. Journal of Research in Personality, 42: $1216-1228$.

Ashton, M., and K. Lee. 2009. The HEXACO-60: A Short Measure of the Major Dimensions of Personality. Journal of Personality Assessment, 91(4): 340-345.

Ashton, M., and K. Lee. 2010. On the Cross-Language Replicability of Personality Factors. Journal of Research in Personality, 44: 436-441.

Ashton, M., K. Lee, and L. Goldberg. 2004. A Hierarchical Analysis of 1,710 English Personality-Descriptive Adjectives. Journal of Personality and Social Psychology, 87: 707-721. 
Ashton, M., K. Lee, M. Perugini, P. Szarota, R. de Vries, L. Di Blas, K. Boies, and B. De Raad. 2004. A Six-Factor Structure of Personality-Descriptive Adjectives: Solutions from Psychological Studies in Seven Languages. Journal of Personality and Social Psychology, 86: 356-366.

Ashton, M., and K. Lee. 2016. Age trends in HEXACO-PI-R Self-Reports. Journal of Research in Personality, 64: 102-111.

Bahns, A., Crandall, C., Gillath, O. and K. Preacher. 2017. Similarity in Relationships as Niche Construction: Choice, Stability, and Influence within Dyads in a Free Choice Environment. Journal of Personality and Social Psychology, 112 (2): 329-355.

Baker, A., Porter, S., ten Brinke, L. and C. Mundy. 2016. Seeing is Believing: Observer Perceptions of Trait Trustworthiness Predict Perceptions of Honesty in High-Stakes Emotional Appeals, Psychology, Crime \& Law.

Baker, T., Lopez, T., Reitenga, A. and G. Ruch. 2019. The Influence of CEO and CFO Power on Accruals and Real Earnings Management. Review of Quantitative Finance and Accounting, 52: 325-345.

Balsam, S. 1998. Discretionary Accounting Choices and CEO Compensation. Contemporary Accounting Research, 15(3): 229-252.

Balsis, S., Cooper, L., and T. Oltmanns. 2015. Are Informant Reports of Personality More Internally Consistent Than Self Reports of Personality? Assessment, 22: 399-404.

Bamber, L., J. Jiang, and I. Wang. 2010. What's My Style? The Influence of Top Managers on Voluntary Corporate Financial Disclosure. The Accounting Review, 85(4): 1131-1162.

Bandiera, O., L. Guiso, A. Prat, and R. Sadun. 2017. "What Do CEOS do?” Review of Financial Studies, Forthcoming.

Bartov, E. and D. Cohen. 2009. The "Numbers Game" in the Pre- and Post-Sarbanes-Oxley Eras. Journal of Accounting, Auditing \& Finance, 24(4): 505-534.

Beatty, A. and J. Weber. 2003. The Effects of Debt Contracting on Voluntary Accounting Method Changes. The Accounting Review, 78(1): 199-142.

Beaudoin, C., Cianci, A., and G. Tsukamis. 2015. The Impact of CFO's Incentives and Earnings Management Ethics on Their Financial Reporting Decisions: The Mediating Role of Moral Disengagement. Journal of Business Ethics, 128(3): 505-518.

Beaussart, M., C. Andrews, and J. Kaufman. 2013. Creative Liars: The Relationship between Creativity and Integrity. Thinking Skills and Creativity, 9: 129-134.

Bergstresser, D. and T. Philippon. 2006. CEO Incentives and Earnings Management. Journal of Financial Economics, 80(3): 511-529.

Berry, D. 1990. Taking People at Face Value: Evidence for the Kernel of Truth Hypothesis. Social Cognition, 8: 343-361. 
Berry, D., and J. Wero. 1993. Accuracy in Face Perception: A View from Ecological Psychology. Journal of Personality, 61(4): 497-520.

Biggerstaff, L., Cicero, D., and A. Puckett. 2015. Suspect CEOs, Unethical Culture, and Corporate Misbehavior. Journal of Financial Economics, 117(1): 98-121.

Bilal, S. and B. Komal. 2018. Audit committee financial expertise and earnings quality: A metaanalysis. Journal of Business Research, 84.

Blankespoor, E., Hendricks, B. and G. Miller. 2017. Perceptions and Price: Evidence from CEO Presentations at IPO Roadshows. Journal of Accounting Research, 55(2): 275-327.

Bond, C., Berry, D., and O. Adnan. 1994. The Kernel of Truth in Judgments of Deceptiveness. Basic \& Applied Social Psychology, 15(4): 523-534.

Borkenau, P., and A. Liebler. 1992. Trait Inferences: Sources of Validity at Zero Acquaintance. Journal of Personality and Social Psychology, 62(4): 645-657.

Borkenau, P., and A. Liebler. 1993. Convergence of Stranger Ratings of Personality and Intelligence with Self-Ratings, Partner Ratings, and Measured Intelligence. Journal of Personality and Social Psychology, 65: 546-553.

Buccholz, F., Lopatta, K. and K. Maas. 2019. The Deliberate Engagement of Narcissistic CEOs in Earnings Management. Journal of Business Ethics, Forthcoming, https://doi.org/10.1007/s10551-019-04176-x.

Carney, D., R. Colvin, and J. Hall. 2007. A Thin Slice Perspective on the Accuracy of First Impressions. Journal of Research in Personality, 41: 1054-1072.

Cerbioni, F., and A. Parbonetti. 2007. Exploring the Effects of Corporate Governance on Intellectual Capital Disclosure: An Analysis of European Biotechnology Companies. European Accounting Review, 16(4): 791-826.

Chan, K., Farrell, B. and P. Lee. 2008. Earnings Management of Firms Reporting Material Internal Control Weaknesses under Section 404 of the Sarbanes-Oxley Act. Auditing: A Journal of Practice \& Theory, 27(2): 161-179.

Chen, W., P. Hribar, and S. Melessa. 2018. Incorrect Inferences When Using Residuals as Dependent Variables. Journal of Accounting Research, 56(3): 751-796.

Chung, J., and S. Hsu. 2017. The Effect of Cognitive Moral Development on Honesty in Managerial Reporting. Journal of Business Ethics, 145: 563-575.

Cohen, D. and P. Zarowin. 2010. Accrual-based and Real Earnings Management Activities Around Seasoned Equity Offerings. Journal of Accounting and Economics, 50(1): 2-19.

Cohen, J., G. Krishnamoorthy and A. Wright. 2010. Corporate Governance in the Post SarbanesOxley Era: Auditors' Experiences. Contemporary Accounting Research, 27(3): 751-786.

Connelly, B. and D. Ones. 2010. An Other Perspective on Personality: Meta-Analytic Integration of Observers' Accuracy and Predictive Validity. Psychological Bulletin, 136(6): 10921122. 
WELCOME TO THE GRAY ZONE

Coram, P., J. Frederickson, and M. Pinnuk. 2017. Earnings Management: The Role of Economics and Ethics on Managers' Decision-Making. Working Paper.

Cormier, D., Lapointe-Antunes, P. and M. Magnan. 2016. CEO Power and CEO Hubris: A Prelude to Financial Misreporting? Management Decision, 54(2): 522-554.

Costa, P., and R. McCrae. 1988. Personality in Adulthood: A Six-Year Longitudinal Study of Self-Reports and Spouse Rating of NEO Personality Inventory. Journal of Personality and Social Psychology, 54(5): 853-863.

CPA Canada. 2011. CAS 240 - The Auditor's Responsibilities Relating to Fraud in an Audit of Financial Statements. CPA Canada, Ontario, Canada.

Crossland, C. and D. Hambrick. 2007. How National Systems Differ in Their Constraints on Corporate Executives: A Study of CEO Effects in Three Countries. Strategic Management Journal, 28(8), 767-789.

Dabbs, J. 1997. Testosterone, Smiling, and Facial Appearance. Journal of Non-verbal Behavior, 21(1): 45-55.

Davidson, R., Dey, A., and A. Smith. 2015. Executives' Off-the-Job Behavior, Corporate Culture, and Financial Reporting Risk. Journal of Financial Economics, 117 (1): 5-28.

Davis, A., Ge, W., Matsumoto, D., and J. Zhang. 2015. The Effect of Manager-Specific Optimism on the Tone of Earnings Conference Calls. Review of Accounting Studies, 20(2): 649-673.

Dechow, P., W. Ge, C. Larson, and R. Sloan. 2011. Predicting Material Accounting Misstatements. Contemporary Accounting Research, 28(1): 17-82.

Dechow, P.., and I. Dichev. 2002. The Quality of Accruals and Earnings: The Role of Accrual Estimation Errors. The Accounting Review, 77(Supplement): 35-59.

Dechow, P.., and D. Skinner. 2000. Earnings Management: Reconciling the Views of Accounting Academics, Practitioners and Regulators. Accounting Horizons, 14(2): 235250.

Dechow, P., R. Sloan., and A. Sweeney. 1995. Detecting Earnings Management. The Accounting Review, 70(2): 193-226.

Dechow, P., R. Sloan, and A. Sweeney. 1996. Causes and Consequences of Earnings Manipulation: An Analysis of Firms Subject to Enforcement Actions by the SEC. Contemporary Accounting Research, 13: 1-36.

Demerjian, P., B. Lev, M. Lewis, and S. McVay. 2013. Managerial Ability and Earnings Quality. The Accounting Review, 88(2): 463-498.

DePaulo, B. M., K. Lanier, and T. Davis. 1983. Detecting the Deceit of the Motivated Liar. Journal of Personality and Social Psychology, 45(5): 1096-1103.

Dichev, I. and D. Skinner. 2002. Large-Sample Evidence on the Debt Covenant Hypothesis. Journal of Accounting Research, 40(4): 1091-1123. 
Dichev, I., Graham, J., Harvey, C. and S. Rajgopal. 2013. Earnings Quality: Evidence from the Field. Journal of Accounting and Economics, 56: 1-33.

Duarte, J., Siegel, S., and L. Young. 2012. Trust and Credit: The Role of Appearance in Peer-toPeer Lending. The Review of Financial Studies, 25(8): 2455-2484.

Efendi, J., A. Srivastava, and E. Swanson. 2007. Why do Corporate Managers Misstate Financial Statements? The Role of Option Compensation and Other Factors. Journal of Financial Economics, 85: 667-708.

Elias, R. 2004. The Impact of Corporate Ethical Values on Perceptions of Earnings Management. Managerial Auditing Journal, 19(1): 84-98.

Evans, J. 2008. Dual-Processing Accounts of Reasoning, Judgment, and Social Cognition. Annual Review of Psychology, 59: 255-278.

Feng, M., W. Ge, S. Luo, and T. Shevlin. 2011. Why do CFOs Become Involved in Material Accounting Manipulations? Journal of Accounting and Economics, 51: 21-36.

Finkelstein, S. and D. Hambrick. 1990. Top Management Team Tenure and Organizational Outcomes: The Moderating Role of Managerial Discretion. Administrative Sciences Quarterly, 35: 484-503.

Finkelstein, S. 1992. Power in Top Management Teams: Dimensions, Measurement, and Validation. Academy of Management Journal, 35(3): 505-538.

Francis, B., Hasan, I., Park, J., and Q. Wu. 2015. Gender Differences in Financial Reporting Decision Making: Evidence from Accounting Conservatism. Contemporary Accounting Research, 32(3): 1285-1318.

Funder, D., and C. Sneed. 1993. Behavioral Manifestations of Personality: An Ecological Approach to Judgmental Accuracy. Journal of Personality and Social Psychology, 64(3): 479-490.

Ge, W. and S. McVay. 2005. The Disclosure of Material Weaknesses in Internal Control after the Sarbanes-Oxley Act. Accounting Horizons, 19(3): 137-158.

Ge, W., D. Matsumoto, and J. Zhang. 2011. Do CFOs Have Style? An Empirical Investigation of the Effect of Individual CFOs on Accounting Practices. Contemporary Accounting Research, 28(4): 1141-1179.

Geniole, S., Molnar, D., Carre, J. and C. McCormick. 2014. The Facial Width-to-Height Ratio Shares Stronger Links with Judgments of Aggression than Judgments of Trustworthiness. Journal of Experimental Psychology, Human Perception and Performance, 40(4): 15261541.

Gomulya, D., E. Wong, M. Ormiston, and W. Boeker. 2017. The Role of Facial Appearance on CEO Selection After Firm Misconduct. Journal of Applied Psychology, 102(4): 617-635. 
Gore, A., E. Yeung and S. Matsunanga. 2008. The Role of Technical Expertise in Firm Governance Structure: Evidence from Chief Financial Officer Contractual Incentives. Strategic Management Journal, 32(7).

Graham, J., Kim, H., and M. Leary. 2019. CEO-Board Dynamics. NBER Working Paper No. 26004.

Gul, F., and S. Leung. 2004. Board Leadership, Outside Directors' Expertise and Voluntary Corporate Disclosures. Journal of Accounting and Public Policy, 23(5): 351-379.

Hall, J., S. Andrzejewski, N. Murphy, M. Mast, and B. Feinstein. 2008. Accuracy of Judging Others' Traits and States: Comparing Mean Levels Across Tests. Journal of Research in Personality, 42: 1476-1489.

Ham, C., Lang, M., Seybert, N., and S. Wang. 2017. CFO Narcissism and Financial Reporting Quality. Journal of Accounting Research, 55(5): 1089-1135.

Hambrick, D., and S. Finkelstein, S. 1987. Managerial Discretion: A Bridge Between Polar Views of Organizations. Research in Organizational Behavior, 9: 369-406.

Hambrick, D. 2007. Upper Echelons Theory: An Update. The Academy of Management Review, 32(2): 334-343.

Hambrick, D. and P. Mason. 1984. Upper Echelons: The Organization as a Reflection of Its Top Managers. The Academy of Management Review, 9(2): 193-206.

Hazarika, S., Karpoff, J., and R. Nahata. 2012. Internal Corporate Governance, CEO Turnover, and Earnings Management. Journal of Financial Economics, 104 (1): 44-69.

Healy, P. 1985. The Effect of Bonus Schemes on Accounting Decisions. Journal of Accounting and Economics, 7: 85-107.

Healy, P. and K. Palepu. 2001. Information Asymmetry, Corporate Disclosure and the Capital Markets: A Review of the Empirical Disclosure Literature. Journal of Accounting and Economics, 31(1-3): 405-440.

Healy, P. and J. Wahlen. 1999. A Review of the Earnings Management Literature and Its Implications for Standard-Setting. Accounting Horizons, 13: 365-383.

Hehman, E., J. Flake, and J. Freeman. 2015. Static and Dynamic Facial Cues Differentially Affect the Consistency of Social Evaluations. Personality and Social Psychology Bulletin, 41(8): 1123-1134.

Hilbig, B., and C. Hessler. 2013. What Lies Beneath: How the Distance Between Truth and Lie Drives Dishonesty. Journal of Experimental Social Psychology, 49: 263-266.

Hilbig, B., and I. Zettler. 2015. When the Cat's Away, Some Mice Will Play: A Basic Trait Account of Dishonest Behavior. Journal of Research in Personality, 57: 72-88.

Ho, S., Li, A., Tam, K., and F. Zhang. 2015. CEO Gender, Ethical Leadership, and Accounting Conservatism. Journal of Business Ethics, 127(2): 351-370. 
Hobson, J., W. Mayew, and M. Venkatachalam. 2012. Analyzing Speech to Detect Financial Misreporting. Journal of Accounting Research, 50(2): 349-392.

Holthausen, R., Larcker, D. and R. Sloan. 1995. Annual Bonus Schemes and the Manipulation of Earnings. Journal of Accounting and Economics, 19(1): 29-74.

Hrazdil, K., J. Novak, R. Rogo, C. Wiedman, and R. Zhang. 2019. Measuring CEO Personality Using Machine-Learning Algorithms: A New Approach and Audit-Fees Based Validity Tests. Journal of Business Finance and Accounting, DOI: 10.1111/jbfa.12406.

Hribar, P., and H. Yang. 2016. CEO Overconfidence and Management Forecasting. Contemporary Accounting Research, 33(1): 204-227.

Hsieh, T.-S., Bedard, J., and K. Johnstone. 2014. CEO Overconfidence and Earnings Management During Shifting Regulatory Regimes. Journal of Business Finance and Accounting, 41(9-10): 1243-1268.

Hsieh, T-S., Wang, Z. and S. Demirkan. 2018. Overconfidence and Tax Avoidance: The Role of CEO and CFO Interaction. Journal of Accounting and Public Policy, 37: 241-253.

Hsieh, T-S., Kim, J-B., Wang, R., and Z. Wang. 2019. Seeing is Believing? Executives' Facial Trustworthiness, Auditor Tenure, and Audit Fees. Journal of Accounting \& Economics, https://doi.org/10.1016/j.jacceco.2019.101260

International Accounting Standards Board. 2019. The Conceptual Framework for Financial Reporting.

Jackson, S. 1992. Consequence of Group Composition for the Interpersonal Dynamics of Strategic Issue Processing. Advances in Strategic Management, 8: 345-382.

Jiang, F., Zhu, B., and J. Huang. 2013. CEO's Financial Experience and Earnings Management. Journal of Multinational Financial Management, 23(3): 134-145.

Jones, K., G. Krishnan, and K. Melendrez. 2008. Do Models of Discretionary Accruals Detect Actual Cases of Fraudulent and Restated Earnings? An Empirical Analysis. Contemporary Accounting Research, 25(2): 499-531.

Jones, D., and D. Paulhus. 2017. Duplicity Among the Dark Triad: Three Faces of Deceit. Journal of Personality and Social Psychology, 113(2): 329-342.

Kahneman, D. 2003. A Perspective on Judgment and Choice - Mapping Bounded Rationality. American Psychologist, 58(9): 697-720.

Kalshoven K., Den Hartog D., and A. De Hoogh. 2011. Ethical Leader Behavior and Big Five Factors of Personality. Journal of Business Ethics, 100: 349-366.

Kaplan, S. 2001. Ethically-Related Judgments by Observers of Earnings Management. Journal of Business Ethics, 32: 285-298. 
Kibeom, L., Ashton, M., Morrison, D., Cordery, J. and P. Dunlop. 2008. Predicting Integrity with the HEXACO Personality Model: Use of Self- and Observer Reports. Journal of Occupational and Organizational Psychology, 81: 147-167.

Kimbrough, MD. 2005. The effect of conference calls on analyst and market underreaction to earnings announcements. The Accounting Review, 80(1): 189-219.

Knutson, B. 1996. Facial Expressions of Emotion Influence Interpersonal Trait Inferences. Journal of Nonverbal Behavior, 20(3): 165-182.

Kothari, S., Leone, A. and C. Wasley. 2005. Performance-matched Discretionary Accruals Measures. Journal of Accounting and Economics, 39: 163-197.

Larcker, D., and A. Zakolyukina. 2012. Detecting Deceptive Discussions in Conference Calls. Journal of Accounting Research, 50(2): 495-540.

Lee, K., and M. Ashton. 2005. Psychopathy, Machiavellianism, and Narcissism in the FiveFactor Model and the HEXACO Model of Personality Structure. Personality and Individual Differences, 38(7): 1571-1582.

Lee, K., and M. Ashton. 2012. The H Factor of Personality. Waterloo, Ontario: Wilfrid Laurier University Press.

Lee, K., M. Ashton, and R. de Vries. 2005. Predicting Workplace Delinquency and Integrity with the HEXACO and Five-Factor Models of Personality Structure. Human Performance, 18: 179-197.

Lee, K., M. Ashton, J. Wiltshire, J. Bourdage, B. Visser, and A. Gallucci. 2013. Sex, Power, and Money: Prediction from the Dark Triad and Honesty-Humility. European Journal of Personality, 27(2): 169-184.

Liu, Y., Wei, Z. and F. Xie. 2016. CFO Gender and Earnings Management: Evidence from China. Review of Quantitative Finance and Accounting, 46(4): 881-905.

Majors, T. 2016. The Interaction of Communicating Measurement Uncertainty and the Dark Triad on Managers' Reporting Decisions. The Accounting Review, 91(3): 973-992.

Marcus, B., K. Lee, and M. Ashton. 2007. Personality Dimensions Explaining Relationships between Integrity Tests and Counterproductive Behavior: Big Five or One in Addition? Personnel Psychology, 60(1): 1-34.

Marcus, J. and J. Roy. 2019. In Search of Sustainable Behaviour: The Role of Core Values and Personality Traits. Journal of Business Ethics, 158: 63-79.

McCrae, R., and P. Costa. 1987. Validation of the Five Factor Model of Personality Across Instruments and Observers. Journal of Personality and Social Psychology, 52(1): 81-90.

Merchant, K. and J. Rockness. 1994. The Ethics of Managing Earnings: An Empirical Investigation. Journal of Accounting and Public Policy, 13: 79-94. 
WELCOME TO THE GRAY ZONE

Mischel, W. (1968). Personality and assessment. Mahwah, New Jersey: Lawrence Erlbaum Associates, Inc., Publishers.

Moberg, D. 1999. The Big Five and Organizational Virtue. Business Ethics Quarterly, 9(2): 245272.

Montag, C. and J. Elhai. 2019. A New Agenda for Personality Psychology in the Digital Age? Personality and Individual Differences, 147(1): 128-134.

Morrison, E., Morris, P., and K. Bard. 2013. The Stability of Facial Attractiveness: Is It What You've Got or What You Do with It? Journal of Nonverbal Behavior, 37: 59-67.

Moshagen, M., Hilbig, B., and I. Zettler. 2018. The Dark Core of Personality. Psychological Review, 125: 656-688.

Muris, P., Merckelbach, H., Otgaar, H., and E. Meijer. 2017. The Malevolent Side of Human Nature: A Meta-analysis and Critical Review of the Literature on the Dark Triad (Narcissism, Machiavellianism, and Psychopathy). Perspectives on Psychological Science, 12: 183-204.

Murphy, N. 2005. Using Thin Slices for Behavioral Coding. Journal of NonVerbal Behavior, 29(4): 235-246.

Murphy, P. 2012. Attitude, Machiavellianism and the Rationalization of Misreporting. Accounting, Organizations and Society, 37: 242-259.

Naumann, L., S. Vazire, P. Rentfrow, and S. Gosling. 2009. Personality Judgments Based on Physical Appearance. Personality and Social Psychology Bulletin, 35(12): 1661-1671.

Nielsen, S. 2010. Top Management Diversity: A Review of Theories and Methodologies. International Journal of Management Reviews, 12(3): 301-316.

Norman, W. T. 1963. Toward an Adequate Taxonomy of Personality Attributes: Replicated Factor Structure in Peer Nomination Personality Ratings. Journal of Abnormal and Social Psychology, 66: 574-583.

Olsen, K., Dworkis, K., and S. Young. 2014. CEO Narcissism and Accounting: A Picture of Profits. Journal of Management Accounting Research, 26(2): 243- 267.

O’Neill, H., Karl, J. and E. Lawrence. 2017. CEO Compensation and Earnings Management: Does Gender Really Matters? Academy of Management Proceedings, 2017(1).

Patelli, L., and M. Pedrini. 2015. Is Tone at the Top Associated with Financial Reporting Aggressiveness? Journal of Business Ethics, 126(1): 3-19.

Paulhus, D., and K. Williams. 2002. The Dark Triad of Personality: Narcissism, Machiavellianism, and Psychopathy. Journal of Research in Personality, 36: 556-563.

Paunonen, S. 1991. On the Accuracy of Ratings of Personality by Strangers. Journal of Personality and Social Psychology, 61(3): 471-477. 
Penton-Voak, I., and J. Chen. 2004. High Salivary Testosterone is Linked to Masculine Male Facial Appearance in Humans. Evolution and Human Behavior, 25(4): 229-241.

Penton-Voak, I., N. Pound, A. Little, and D. Perrett. 2006. Personality Judgments from Natural and Composite Facial Images: More Evidence for a "Kernel of Truth" in Social Perception. Social Cognition, 24(5): 607-640.

Pinto, J., C. Leana, and F. Pil. 2008. Corrupt Organizations or Organizations of Corrupt Individuals? Two Types of Organization-Level Corruption. Academy of Management Review, 33(3): 685-709.

Plöckinger, M., E. Aschauer., M. Hiebl, and R. Rohatschek. 2016. The Influence of Individual Executives on Corporate Financial Reporting: A Review and Outlook from the Perspective of Upper Echelons Theory. Journal of Accounting Literature, 37: 55-75.

Pohling, R., Bzdok, D., Eigenstetter, M., Stumpf, S., and A. Strobel. 2016. What is Ethical Competence? The Role of Empathy, Personal Values, and the Five-Factor Model of Personality in Ethical Decision-Making. Journal of Business Ethics, 137: 449-474.

Porter, S., and J. Yuille. 1995. Credibility Assessment of Criminal Suspects through Statement Analysis. Psychology, Crime, and Law, 1: 319-331.

Porter, S., J. Yuille, and D. Lehman. 1999. The Nature of Real, Implanted and Fabricated Memories for Emotional Childhood Events: Implications for the Recovered Memory Debate. Law and Human Behavior, 23: 517-537.

Porter, S., L. England, M. Juodis, L. ten Brinke and K. Wilson. 2008. Is the Face a Window to the Soul? Investigation of the Accuracy of Intuitive Judgments of the Trustworthiness of Human Faces. Canadian Journal of Behavioural Science, 40(3): 171-177.

Prottas, D. 2013. Relationships Among Employee Perception of Their Manager's Behavioral Integrity, Moral Distress, and Employee Attitudes and Well-Being. Journal of Business Ethics, 113(1): 51-60.

Ran, G., Fang, Q., Luo, S., and K. Chan. 2015. Supervisory Board Characteristics and Accounting Information Quality: Evidence from China. International Review of Economics \& Finance, 37: 18-32.

Roberts, B., and W. DelVecchio. 2000. The Rank-Order Consistency of Personality from Childhood to Old Age: A Quantitative Review of Longitudinal Studies. Psychological Bulletin, 126: 3-25.

Roberts, B., K., Walton, and W. Viechtbauer. 2006. Patterns of Mean-Level Change in Personality Traits Across the Life Course: A Meta-Analysis of Longitudinal Studies. Psychological Bulletin, 132: 1-25.

Roychowdhury, S., 2006. Earnings Management Through Real Activities Manipulation. Journal of Accounting and Economics, 42: 335-370.

Rule, N., and N. Ambady. 2008. The Face of Success - Inferences from Chief Executive Officers' Appearance Predict Company Profits. Psychological Science, 19(2): 109-111. 
Rule, N., Krendl, A., Ivcevic, Z. and N. Ambady. 2013. Accuracy and Consensus in Judgments of Trustworthiness from Faces: Behavioral and Neural Correlates. Journal of Personality and Social Psychology, 104(3): 409-426.

Russell Reynolds. 2015. Inside the Mind of the CFO. https://www.russellreynolds.com/insights/thought-leadership/inside-the-mind-of-the-cfo

Schrand, C. and S. Zechman. 2012. Executive Overconfidence and the Slippery Slope to Financial Misreporting. Journal of Accounting and Economics, 53: 311-329.

Shevlin, M., Walker, S., Davies, M., Banyard, P. and C. Lewis. 2002. Can you Judge a Book by Its Cover? Evidence of Self-Stranger Agreement on Personality at Zero Acquaintance. Personality and Individual Differences, 35: 1373-1383.

Simha, A. and K. Parboteeah. 2019. The Big 5 Personality Traits and Willingness to Justify Unethical Behavior - A Cross-National Examination. Journal of Business Ethics, https://doi.org/10.1007/s10551-019-04142-7.

Simsek, Z., Heavey, C. and B. Fox. 2017. Interfaces of Strategic Leaders: A Conceptual Framework, Review and Research Agenda. Journal of Management, 44(1): 280-324.

Slepian, M., and D. Ames. 2016. Internalized Impressions: The Link Between Apparent Facial Trustworthiness and Deceptive Behavior Is Mediated by Targets' Expectations of How They Will Be Judged. Psychological Science, 27(2): 282-288.

Stillman, T., Maner, J., and R. Baumeister. 2010. A Thin Slice of Violence: Distinguishing Violent from Nonviolent Sex Offenders at a Glance. Evolution and Human Behavior, 31(4): 298-303.

Sutherland, C., A. Young, and G. Rhodes. 2017. Facial First Impressions from Another Angle: How Social Judgements are Influenced by Changeable and Invariant Facial Properties. British Journal of Psychology, 108: 397-415.

Sweeney, A. 1994. Debt-covenant Violations and Managers' Accounting Responses. Journal of Accounting and Economics, 17: 281-308.

Tingley, D. 2014. Face-Off: Facial Features and Strategic Choice. Political Psychology, 35(1): 35-55.

Todorov, A., and J. Porter. 2014. Misleading First Impressions: Different for Different Facial Images of the Same Person. Psychological Science, 25: 1404-1417.

Troy, C., Smith, K., and M. Domino. 2011. CEO Demographics and Accounting Fraud: Who is More Likely to Rationalize Illegal Acts? Strategic Organization, 9 (4): 259-282.

Van Scotter, J. and K. Roglio. 2019. CEO Bright and Dark Personality: Effects of Ethical Misconduct. Journal of Business Ethics, https://doi.org/10.1007/s10551-018-4061-5.

Vazire, S. 2006. Informant Reports: A Cheap, Fast, and Easy Method for Personality Assessment. Journal of Research in Personality, 40: 472-481. 
WELCOME TO THE GRAY ZONE

Vrij, A., 2000. Detecting Lies and Deceit: The Psychology of Lying and the Implications for Professional Practice. Chichester: Wiley.

Vrij, A., L. Akehurst, R. Soukara, and R. Bull. 2004. Detecting Deceit via Analyses of Verbal and Nonverbal Behavior in Adults and Children. Human Communication Research, 30: $8-41$.

Wang, G., Holmes, R. M., Oh, I.-S., \& Zhu, W. 2016. Do CEOs Matter to Firm Strategic Actions and Firm Performance? A Metaanalytic Investigation Based on Upper Echelons Theory. Personnel Psychology, 69(4): 775-862.

Watson, D. 1989. Strangers' Ratings of the Five Robust Personality Factors: Evidence of a Surprising Convergence with Self-Report. Journal of Personality and Social Psychology, 57: 120-128.

Willis, J. and A. Todorov. 2006. First Impressions - Making Up Your Mind after a 100-Ms Exposure to a Face. Psychological Science, 17(7): 592-598.

Willis, M., R. Palermo, and D. Burke. 2011. Social Judgments are Influenced by both Facial Expression and Direction of Eye Gaze. Social Cognition, 29: 415-429.

Wilson, P. and N. Rule. 2017. Advances in Understanding the Detectability of Trustworthiness from the Face: Toward a Taxonomy of a Multifaceted Construct. Current Directions in Psychological Science, 26(4): 396 -400.

Zang, A. 2012. Evidence on the Trade-Off between Real Activities Manipulation and AccrualBased Earnings Management. The Accounting Review, 87(2): 675-703.

Zebrowitz L., and M. Collins. 1997. Accurate Social perception at Zero Acquaintance: The Affordances of a Gibsonian Approach. Personality and Social Psychology Review, 1(3): 204-223.

Zebrowitz, L., M. Kikuchi, and J. Fellous. 2007. Are Effects of Emotion Expression on Trait Impressions Mediated by Babyfaceness? Evidence from Connectionist Modeling. Personality and Social Psychology Bulletin, 33: 648-662.

Zebrowitz, L., L. Voinescu, and M. Collins. 1996. "Wide-Eyed" and "Crooked-Faced": Determinants of Perceived and Real Honesty Across the Life Span. Personality and Social Psychology Bulletin, 22(12): 1258-1269.

Zettler, I., and B. Hilbig. 2010. Honesty-Humility and a Person-Situation-Interaction at Work. European Journal of Personality, 24(7): 569-582.

Zhang, X., K. Bartol, K. Smith, M. Pfarrer, and D. Khanin. 2008. CEOs on the Edge: Earnings Manipulation and Stock-Based Incentive Misalignment. Academy of Management Journal, 51(2): 241-258. 


\section{APPENDIX A Variable Definitions}

\begin{tabular}{|c|c|}
\hline$A B A C C$ & $\begin{array}{l}\text { Absolute value of the estimated residuals from the following industry-year } \\
\text { regression (with at least } 15 \text { observations) using the Dechow, Sloan and } \\
\text { Sweeney (1995) and Kothari, Leone and Wasley (2005) equations; } \\
\qquad \frac{\text { TotalAccruals }_{t}}{\text { Assets }_{t-1}}=\alpha_{1}\left(\frac{1}{\text { Assets }_{t-1}}\right)+\frac{\beta_{1}\left(\Delta S_{t}-\triangle A R_{t}\right)}{\text { Assets }_{t-1}}+\beta_{2}\left(\frac{P P E_{t-1}}{\text { Assets }_{t-1}}\right)+ \\
\qquad \beta_{3} R O A_{t-1}+\varepsilon_{t} \\
\text { where TotalAccruals equals net income before extraordinary items minus } \\
\text { operating cash flows, } \triangle S \text { is change in sales revenue, } \triangle A R \text { is change in } \\
\text { accounts receivables, } P P E \text { is net property, plant and equipment, } R O A \text { is return } \\
\text { on assets, and Assets }{ }_{t-1} \text { are lagged total assets. Higher values indicate more } \\
\text { accruals management (lower quality earnings). }\end{array}$ \\
\hline DICHEV & $\begin{array}{l}\text { Absolute value of the estimated residuals from the following industry-year } \\
\text { regression (with at least } 15 \text { observations) using the Dechow-Dichev (2002) } \\
\text { equation; } \\
\qquad W C=\alpha_{0}+\beta_{1} C F O_{t-1}+\beta_{2} C F O_{t}+\beta_{3} C F O_{t+1}+\varepsilon_{t} \\
\text { where } W C \text { is working capital accruals; and } C F O_{\mathrm{t}-1}, C F O_{\mathrm{t}} \text {, and } C F O_{\mathrm{t}+1} \text { are past, } \\
\text { current, and future cash flows from operations, respectively. Higher values } \\
\text { indicate more accruals management (lower quality earnings). }\end{array}$ \\
\hline$A B C F O$ & $\begin{array}{l}\text { Absolute value of the estimated residuals from the following industry-year } \\
\text { regression (with at least } 15 \text { observations) using the Roychowdhury (2006) and } \\
\text { Zang (2012) equation; } \\
\qquad \frac{C F O_{t}}{A_{t-1}}=\alpha_{0}+\alpha_{1}\left(\frac{1}{A_{t-1}}\right)+\alpha_{2}\left(\frac{S_{t}}{A_{t-1}}\right)+\alpha_{3}\left(\frac{\Delta S_{t}}{A_{t-1}}\right)+\epsilon_{t} \\
\text { where } C F O_{t} \text {, is cash flows from operations, } A \text { is total assets and } S \text { is net sales. } \\
\text { Higher values indicate greater amounts of sales manipulation to manage } \\
\text { reported earnings. }\end{array}$ \\
\hline$A B E X P$ & $\begin{array}{l}\text { Absolute value of the estimated residuals from the following industry-year } \\
\text { regression (with at least } 15 \text { observations) using the Roychowdhury (2006) and } \\
\text { Zang (2012) equation; } \\
\qquad \frac{D I S X_{t}}{A_{t-1}}=\alpha_{0}+\alpha_{1}\left(\frac{1}{A_{t-1}}\right)+\alpha_{2}\left(\frac{S_{t-1}}{A_{t-1}}\right)+\epsilon_{t} \\
\text { where DISX is the sum of advertising, research and development and SGA } \\
\text { expenses (XAD + XRD + XSGA), } A \text { is total assets, and } S \text { is sales. Higher } \\
\text { values indicate greater fluctuations in discretionary expenses to manage } \\
\text { reported earnings. }\end{array}$ \\
\hline
\end{tabular}




\section{APPENDIX A (continued) Variable Definitions}

\begin{tabular}{|c|c|}
\hline$A B P R O D$ & $\begin{array}{l}\text { Absolute value of the estimated residuals from the following industry-year } \\
\text { regression (with at least } 15 \text { observations) using the Roychowdhury (2006) and } \\
\text { Zang (2012) equation; } \\
\qquad \frac{P R O D_{t}}{A_{t-1}}=\alpha_{0}+\alpha_{1}\left(\frac{1}{A_{t-1}}\right)+\alpha_{2}\left(\frac{S_{t}}{A_{t-1}}\right)+\alpha_{3}\left(\frac{\Delta S_{t}}{A_{t-1}}\right)+\alpha_{4}\left(\frac{\Delta S_{t-1}}{A_{t-1}}\right)+\epsilon_{t} \\
\text { where } P R O D \text { is cost of goods plus change in inventory, } A \text { is total assets, } S \text { is } \\
\text { sales, } \triangle S \text { is change in sales revenue. Higher vales indicate higher amounts of } \\
\text { under- or overproduction to manage COGS and reported earnings. }\end{array}$ \\
\hline REMI & $A B E X P+A B P R O D$ \\
\hline REM2 & $A B C F O+A B E X P$ \\
\hline HONESTY & $\begin{array}{l}\text { Normalized mean honesty score (between } 0 \text { and 1) for each CFO and CEO } \\
\text { picture calculated from reliable raters' scores. }\end{array}$ \\
\hline CEOPOWER & $\begin{array}{l}\text { Indicator variable equal to } 1 \text { if the } \mathrm{CEO} \text { is also Chairman of the Board, and } 0 \\
\text { otherwise. }\end{array}$ \\
\hline CFOSTCKCOMP & Ratio of CFO equity-based pay to total annual compensation. \\
\hline CFOBONUS & Ratio of CFO bonus-based pay to total annual compensation. \\
\hline CEOSTCKCOMP & Ratio of CEO equity-based pay to total annual compensation. \\
\hline CEOBONUS & Ratio of CEO bonus-based pay to total annual compensation. \\
\hline AVERBONUS & Simple average of $C E O B O N U S$ and $C F O B O N U S$ \\
\hline AVERSTCKCOMP & Simple average of CEOSTCKCOMP and CFOSTCKCOMP. \\
\hline LOSS & Indicator variable equal to 1 if net income is negative, and 0 otherwise. \\
\hline LEVERAGE & Ratio of total debt $(D L C+D L T T)$ to total assets $(A T)$ \\
\hline SECTION302 & $\begin{array}{l}\text { Indicator variable equal to } 1 \text { if the company reports internal control } \\
\text { deficiencies under SOX Section } 302 \text {, and } 0 \text { otherwise. }\end{array}$ \\
\hline PERCAUDITFEES & Ratio of audit and audit-related fees to total fees. \\
\hline SIZE & Natural logarithm of total assets. \\
\hline$M T B$ & $\begin{array}{l}\text { Ratio of the market value of common shares at the end of the fiscal year } \\
\left(P R C C_{-} F^{*} C H S O\right) \text { to the book value of common shares }(C E Q) \text {. }\end{array}$ \\
\hline$R O A$ & $\begin{array}{l}\text { Ratio of income before extraordinary items }(I B) \text { to beginning of period total } \\
\text { assets }(A T) \text {. }\end{array}$ \\
\hline CFOGENDER & Indicator variable equal to 1 if the CFO is a male, and 0 otherwise. \\
\hline CEOGENDER & Indicator variable equal to 1 if the CEO is a male, and 0 otherwise. \\
\hline
\end{tabular}


WELCOME TO THE GRAY ZONE

\section{APPENDIX B \\ Honesty/Humility Observer Report Form}

\section{Question \# $\quad$ Question}

1

2

3

4

5

6

7

8

9

10
$\mathrm{He} / \mathrm{she}$ wouldn't use flattery to get a raise or promotion at work, even if he/she thought it would succeed.

If he/she knew that he/she could never get caught, he/she would be willing to steal a million dollars. (reverse coded)

Having a lot of money is not especially important to him/her.

$\mathrm{He} / \mathrm{she}$ thinks that he/she is entitled to more respect than the average person is. (reverse coded)

If he/she wants something from someone, he/she will laugh at that person's worst jokes. (reverse coded)

$\mathrm{He} / \mathrm{she}$ would never accept a bribe, even if it were very large.

$\mathrm{He} / \mathrm{she}$ would get a lot of pleasure from owning expensive luxury goods. (reverse coded)

$\mathrm{He} / \mathrm{she}$ wants people to know that he/she is an important person of high status. (reverse coded)

He/she wouldn't pretend to like someone just to get that person to do favours for him/her.

He/she'd be tempted to use counterfeit money, if he/she were sure he/she could get away with it. (reverse coded) 
WELCOME TO THE GRAY ZONE

APPENDIX C

Honesty/Humility Self Report Form

\section{Question \#}

1

2

\section{Question}

I wouldn't use flattery to get a raise or promotion at work, even if I thought it would succeed.

If I knew that I could never get caught, I would be willing to steal a million dollars. (reverse coded)

Having a lot of money is not especially important to me.

I think that I am entitled to more respect than the average person is. (reverse coded)

If I want something from someone, I will laugh at that person's worst jokes. (reverse coded)

I would never accept a bribe, even if it were very large.

I would get a lot of pleasure from owning expensive luxury goods. (reverse coded)

I want people to know that I am an important person of high status. (reverse coded)

I wouldn't pretend to like someone just to get that person to do favours for me.

I would be tempted to use counterfeit money, if I were sure I could get away with it. (reverse coded) 
TABLE 1

Descriptive Statistics

This table reports descriptive statistics for the variables included in the regression models. Variable definitions are provided in Appendix A.

\begin{tabular}{|l|r|r|r|r|r|r|}
\hline \multicolumn{1}{|c|}{ Variable } & \multicolumn{1}{c|}{$\mathrm{N}$} & \multicolumn{1}{c|}{ Mean } & \multicolumn{1}{c|}{ Median } & \multicolumn{1}{c|}{ Minimum } & Maximum & $\begin{array}{c}\text { Standard } \\
\text { deviation }\end{array}$ \\
\hline ABACC & 881 & 0.0978 & 0.0555 & 0.0004 & 0.5679 & 0.1097 \\
\hline DICHEV & 911 & 0.0808 & 0.0398 & 0.0003 & 0.5034 & 0.0969 \\
\hline REM1 & 867 & 0.3833 & 0.2989 & 0.0012 & 1.6749 & 0.3414 \\
\hline REM 2 & 887 & 0.4193 & 0.2879 & 0.0028 & 2.1774 & 0.4237 \\
\hline CFOHONESTY & 950 & 0.4930 & 0.4963 & 0.0000 & 1.0000 & 0.1941 \\
\hline CEOHONESTY & 950 & 0.4723 & 0.4712 & 0.0000 & 1.0000 & 0.2208 \\
\hline CEOPOWER & 843 & 0.5338 & 1.0000 & 0.0000 & 1.0000 & 0.4992 \\
\hline CFOSTCKCOMP & 947 & 0.7396 & 0.7663 & 0.0000 & 0.9909 & 0.1314 \\
\hline CFOBONUS & 946 & 0.0296 & 0.0000 & 0.0000 & 0.7875 & 0.0893 \\
\hline CEOSTCKCOMP & 948 & 0.8159 & 0.8489 & 0.0000 & 0.9865 & 0.1324 \\
\hline CEOBONUS & 949 & 0.0227 & 0.0000 & 0.0000 & 0.4957 & 0.0752 \\
\hline AVERSTCKCOMP & 946 & 0.7776 & 0.8056 & 0.0000 & 0.9826 & 0.1181 \\
\hline AVERBONUS & 946 & 0.0261 & 0.0000 & 0.0000 & 0.5307 & 0.0766 \\
\hline LOSS & 949 & 0.0527 & 0.0000 & 0.0000 & 1.0000 & 0.2235 \\
\hline LEVERAGE & 913 & 0.2459 & 0.2209 & 0.0000 & 0.8920 & 0.1604 \\
\hline SECTION3O2 & 845 & 0.1195 & 0.0000 & 0.0000 & 1.0000 & 0.3246 \\
\hline PERCAUDITFEES & 853 & 0.8795 & 0.9122 & 0.0909 & 1.0000 & 0.1196 \\
\hline SIZE & 918 & 9.8102 & 9.6535 & 7.1695 & 12.5561 & 1.2341 \\
\hline MTB & 918 & 1.8295 & 1.5309 & 0.7931 & 8.4102 & 0.9799 \\
\hline ROA & 918 & 0.0620 & 0.0534 & -0.2958 & 0.3343 & 0.0562 \\
\hline CFOGENDER & 950 & 0.8874 & 1.0000 & 0.0000 & 1.0000 & 0.3163 \\
\hline CEOGENDER & 948 & 0.9641 & 1.0000 & 0.0000 & 1.0000 & 0.1861 \\
\hline
\end{tabular}




\section{WELCOME TO THE GRAY ZONE}

TABLE 2

\section{Correlations}

This table reports pairwise correlations between variables of interest. p-values are shown in brackets. ***, **, and * denote statistical significance at $1 \%, 5 \%$, and $10 \%$ levels, respectively.

\begin{tabular}{|c|c|c|c|c|c|c|}
\hline & CFOHONESTY & CEOHONESTY & $A B A C C$ & DICHEV & REMI & REM2 \\
\hline CFOHONESTY & 1.0000 & & & & & \\
\hline CEOHONESTY & $\begin{array}{r}0.0771^{* *} \\
(0.018)\end{array}$ & 1.0000 & & & & \\
\hline$A B A C C$ & $\begin{array}{r}-0.0552 \\
(0.101)\end{array}$ & $\begin{array}{r}-0.0052 \\
(0.878)\end{array}$ & 1.0000 & & & \\
\hline DICHEV & $\begin{array}{r}-0.0897 * * * \\
(0.007)\end{array}$ & $\begin{array}{r}0.0135 \\
(0.684)\end{array}$ & $\begin{array}{r}0.3539 * * * \\
(0.000)\end{array}$ & 1.0000 & & \\
\hline REMI & $\begin{array}{r}-0.0779 * * \\
(0.021)\end{array}$ & $\begin{array}{r}-0.0087 \\
(0.798)\end{array}$ & $\begin{array}{r}0.5619 * * * \\
(0.000)\end{array}$ & $\begin{array}{r}0.5021 * * * \\
(0.000)\end{array}$ & 1.0000 & \\
\hline REM2 & $\begin{array}{r}-0.0820 * * \\
(0.015)\end{array}$ & $\begin{array}{r}0.0129 \\
(0.702)\end{array}$ & $\begin{array}{r}0.5724 * * * \\
(0.000)\end{array}$ & $\begin{array}{r}0.5560 * * * \\
(0.000)\end{array}$ & $\begin{array}{r}0.9386^{* * * *} \\
(0.000)\end{array}$ & 1.0000 \\
\hline
\end{tabular}


WELCOME TO THE GRAY ZONE

TABLE 3

Frequency Table

This table presents a frequency table for CFO and CEO perceived honesty scores. Variables are defined in Appendix A. The relationship between CFO and CEO classification factors is tested with a Chi-2 test. ***, **, and * denote statistical significance at $1 \%, 5 \%$, and $10 \%$ levels, respectively.

\begin{tabular}{|c|r|r|r|}
\hline \multirow{2}{*}{ CFOHONESTY } & \multicolumn{2}{|c|}{ CEOHONESTY } & \\
\cline { 2 - 4 } & <MEDIAN & >=MEDIAN & TOTAL \\
\hline <MEDIAN & 263 & 212 & 475 \\
\hline >=MEDIAN & 211 & 264 & 475 \\
\hline TOTAL & 474 & 476 & 950 \\
\hline PEARSON CHI-2 & \multicolumn{3}{|c|}{$11.3853^{* * * *}$} \\
\hline
\end{tabular}


TABLE 4

\section{Differences in Means}

This table compares mean values for real earnings management and accruals management measures across subgroups of sample firms. The first two panels compare mean values for subgroups based on perceived honesty (HONESTY) for CFOs and CEOs respectively. The last panel compares mean values for subgroups of CFOs and CEOs with matching levels of perceived honesty. Variables are defined in Appendix A. Results are based on one-tailed t-tests of differences in means. ***,**, and * denote statistical significance at $1 \%, 5 \%$, and $10 \%$ levels, respectively.

\begin{tabular}{|c|c|c|c|c|c|c|c|}
\hline & $\begin{array}{l}\text { Bottom quartile } \\
\text { (BQ) }\end{array}$ & $\begin{array}{l}\text { Bottom } 3 \\
\text { quartiles } \\
\text { (B3Q) }\end{array}$ & $\begin{array}{c}\text { Top } 3 \text { quartiles } \\
\text { (T3Q) }\end{array}$ & $\begin{array}{c}\text { Top quartile } \\
\text { (TQ) }\end{array}$ & $\begin{array}{c}\text { Diff. } \\
(\mathrm{BQ}-\mathrm{T} 3 \mathrm{Q})\end{array}$ & $\begin{array}{c}\text { Diff. } \\
\text { (B3Q - TQ) }\end{array}$ & $\begin{array}{c}\text { Diff. } \\
(\mathrm{BQ}-\mathrm{TQ})\end{array}$ \\
\hline$A B A C C$ & 0.0973 & 0.1021 & 0.0980 & 0.0856 & -0.0007 & $0.0165^{* *}$ & 0.0117 \\
\hline DICHEV & 0.0942 & 0.0859 & 0.0765 & 0.0655 & $0.0177^{\text {**** }}$ & $0.0204^{\text {**** }}$ & $0.0287^{\text {***** }}$ \\
\hline REM1 & 0.4151 & 0.4006 & 0.3740 & 0.3314 & $0.0411^{*}$ & $0.0692^{* * *}$ & $0.0837^{\text {**** }}$ \\
\hline REM2 & 0.4626 & 0.4394 & 0.4066 & 0.3604 & $0.0560^{*}$ & $0.0789^{\text {*** }}$ & $0.1022^{\text {*** }}$ \\
\hline & $\begin{array}{c}\text { Bottom quartile } \\
\text { (BQ) }\end{array}$ & $\begin{array}{l}\text { Bottom } 3 \\
\text { quartiles } \\
\text { (B3Q) }\end{array}$ & $\begin{array}{c}\text { Top } 3 \text { quartiles } \\
\text { (T3Q) }\end{array}$ & $\begin{array}{l}\text { Top quartile } \\
\text { (TQ) }\end{array}$ & $\begin{array}{c}\text { Diff. } \\
(\mathrm{BQ}-\mathrm{T} 3 \mathrm{Q})\end{array}$ & $\begin{array}{c}\text { Diff. } \\
(\mathrm{B} 3 \mathrm{Q}-\mathrm{TQ})\end{array}$ & $\begin{array}{c}\text { Diff. } \\
(\mathrm{BQ}-\mathrm{TQ})\end{array}$ \\
\hline$A B A C C$ & 0.0994 & 0.0986 & 0.0973 & 0.0956 & 0.0020 & 0.0030 & 0.0038 \\
\hline DICHEV & 0.0908 & 0.0802 & 0.0773 & 0.0824 & $0.0136^{* *}$ & -0.0021 & 0.0085 \\
\hline REM1 & 0.4018 & 0.3865 & 0.3769 & 0.3735 & 0.0249 & 0.0130 & 0.0283 \\
\hline REM2 & 0.4217 & 0.4210 & 0.4184 & 0.4139 & 0.0033 & 0.0071 & 0.0078 \\
\hline
\end{tabular}

\begin{tabular}{|c|c|c|c|c|c|c|}
\hline & \multicolumn{6}{|c|}{ QUARTILES } \\
\hline & $\mathrm{BQ} / \mathrm{BQ}=1$ & $\begin{array}{c}\mathrm{BQ} / \mathrm{BQ} \\
=0\end{array}$ & Diff. & $\begin{array}{c}\text { TQ/TQ } \\
=0\end{array}$ & $\begin{array}{c}\text { TQ/TQ } \\
=1\end{array}$ & Diff. \\
\hline$A B A C C$ & 0.0946 & 0.0981 & -0.0035 & 0.0993 & 0.0769 & $0.0224^{*}$ \\
\hline REM1 & 0.4100 & 0.3812 & 0.0288 & 0.3917 & 0.2613 & $0.1304^{\text {**** }}$ \\
\hline REM2 & 0.4208 & 0.3998 & 0.0210 & 0.4298 & 0.2655 & $0.1643^{\text {**** }}$ \\
\hline
\end{tabular}




\section{WELCOME TO THE GRAY ZONE}

\section{TABLE 5}

\section{Perceived Honesty and Earnings Management}

This table reports the OLS regression results of earnings management on perceived CFO honesty (Panel A), CEO honesty (Panel B) and CFO and CEO honesty (Panel C). Variable definitions are provided in Appendix A. ***, **, and * denote statistical significance at 1\%, 5\%, and 10\% levels, respectively.

\begin{tabular}{|c|c|c|c|c|c|c|c|c|c|c|c|c|}
\hline Panel A & \multicolumn{3}{|c|}{$A B A C C$} & \multicolumn{3}{|c|}{ DICHEV } & \multicolumn{3}{|c|}{ REMI } & \multicolumn{3}{|c|}{ REM2 } \\
\hline CFOHONESTY & $\begin{array}{r}-0.031 * * \\
(0.016)\end{array}$ & & & $\begin{array}{r}-0.048^{*} \\
(0.067)\end{array}$ & & & $\begin{array}{r}-0.168 * * * \\
(0.007)\end{array}$ & & & $\begin{array}{r}-0.225 * * * \\
(0.001)\end{array}$ & & \\
\hline CFOTOPQ & & $\begin{array}{r}-0.008 \\
(0.253) \\
\end{array}$ & & & $\begin{array}{r}-0.018 * * \\
(0.044) \\
\end{array}$ & & & $\begin{array}{r}-0.058 * * \\
(0.020) \\
\end{array}$ & & & $\begin{array}{r}-0.067 * * \\
(0.019) \\
\end{array}$ & \\
\hline СFОВОТТОМQ & & & $\begin{array}{r}0.010 \\
(0.142)\end{array}$ & & & $\begin{array}{l}0.026^{*} \\
(0.071)\end{array}$ & & & $\begin{array}{r}0.074 * * \\
(0.017)\end{array}$ & & & $\begin{array}{r}0.109 * * \\
(0.030)\end{array}$ \\
\hline СFOSTOCКСОМР & $\begin{array}{l}0.070 * \\
(0.079)\end{array}$ & $\begin{array}{l}0.070^{*} \\
(0.085)\end{array}$ & $\begin{array}{l}0.073^{*} \\
(0.078)\end{array}$ & $\begin{array}{l}0.056^{*} \\
(0.082)\end{array}$ & $\begin{array}{l}0.054^{*} \\
(0.082)\end{array}$ & $\begin{array}{l}0.062 * \\
(0.057)\end{array}$ & $\begin{array}{l}0.245^{*} \\
(0.073)\end{array}$ & $\begin{array}{l}0.239 * \\
(0.075)\end{array}$ & $\begin{array}{r}0.268 * * \\
(0.048)\end{array}$ & $\begin{array}{r}0.289 * * \\
(0.016)\end{array}$ & $\begin{array}{r}0.282 * * \\
(0.018)\end{array}$ & $\begin{array}{r}0.318^{* * * *} \\
(0.006)\end{array}$ \\
\hline CFOBONUS & $\begin{array}{r}0.112 \\
(0.234)\end{array}$ & $\begin{array}{r}0.117 \\
(0.214)\end{array}$ & $\begin{array}{r}0.115 \\
(0.227)\end{array}$ & $\begin{array}{r}0.048 \\
(0.385)\end{array}$ & $\begin{array}{r}0.052 \\
(0.364)\end{array}$ & $\begin{array}{r}0.050 \\
(0.354)\end{array}$ & $\begin{array}{r}-0.053 \\
(0.725)\end{array}$ & $\begin{array}{r}-0.043 \\
(0.767)\end{array}$ & $\begin{array}{r}-0.038 \\
(0.786)\end{array}$ & $\begin{array}{r}-0.011 \\
(0.914)\end{array}$ & $\begin{array}{r}0.004 \\
(0.968)\end{array}$ & $\begin{array}{r}0.006 \\
(0.947)\end{array}$ \\
\hline LOSS & $\begin{array}{r}-0.006 \\
(0.650) \\
\end{array}$ & $\begin{array}{r}-0.005 \\
(0.684) \\
\end{array}$ & $\begin{array}{r}-0.005 \\
(0.669) \\
\end{array}$ & $\begin{array}{r}0.057 * * \\
(0.015)\end{array}$ & $\begin{array}{r}0.058 * * \\
(0.016)\end{array}$ & $\begin{array}{r}0.057 * * \\
(0.016) \\
\end{array}$ & $\begin{array}{r}0.063 \\
(0.158) \\
\end{array}$ & $\begin{array}{r}0.067 \\
(0.142) \\
\end{array}$ & $\begin{array}{r}0.062 \\
(0.169) \\
\end{array}$ & $\begin{array}{r}0.081 * * \\
(0.024)\end{array}$ & $\begin{array}{r}0.083^{* * *} * \\
(0.006)\end{array}$ & $\begin{array}{r}0.077 * * \\
(0.050)\end{array}$ \\
\hline$L E V E R A G E$ & $\begin{array}{r}0.063 * \\
(0.066) \\
\end{array}$ & $\begin{array}{l}0.061 * \\
(0.072) \\
\end{array}$ & $\begin{array}{r}0.065^{*} \\
(0.061) \\
\end{array}$ & $\begin{array}{r}0.027 * \\
(0.100) \\
\end{array}$ & $\begin{array}{r}0.023 \\
(0.141) \\
\end{array}$ & $\begin{array}{l}0.031 * \\
(0.089) \\
\end{array}$ & $\begin{array}{r}-0.096 \\
(0.101) \\
\end{array}$ & $\begin{array}{r}-0.106^{*} \\
(0.089) \\
\end{array}$ & $\begin{array}{r}-0.080 \\
(0.137) \\
\end{array}$ & $\begin{array}{r}0.000 \\
(0.981) \\
\end{array}$ & $\begin{array}{r}-0.014 \\
(0.555) \\
\end{array}$ & $\begin{array}{r}0.023 \\
(0.369) \\
\end{array}$ \\
\hline SECTION302 & $\begin{array}{r}0.011 \\
(0.293) \\
\end{array}$ & $\begin{array}{r}0.011 \\
(0.301) \\
\end{array}$ & $\begin{array}{r}0.012 \\
(0.306) \\
\end{array}$ & $\begin{array}{r}0.018 \\
(0.207) \\
\end{array}$ & $\begin{array}{r}0.017 \\
(0.223) \\
\end{array}$ & $\begin{array}{r}0.018 \\
(0.187) \\
\end{array}$ & $\begin{array}{r}0.121 * * * \\
(0.006) \\
\end{array}$ & $\begin{array}{r}0.120 * * * \\
(0.005) \\
\end{array}$ & $\begin{array}{r}0.122 * * * \\
(0.007) \\
\end{array}$ & $\begin{array}{r}0.122 * * \\
(0.042) \\
\end{array}$ & $\begin{array}{r}0.121 * * \\
(0.040) \\
\end{array}$ & $\begin{array}{r}0.124 * * \\
(0.046) \\
\end{array}$ \\
\hline PERCAUDITFEES & $\begin{array}{r}-0.082 * \\
(0.072) \\
\end{array}$ & $\begin{array}{r}-0.085^{*} \\
(0.077) \\
\end{array}$ & $\begin{array}{r}-0.085^{*} \\
(0.063) \\
\end{array}$ & $\begin{array}{r}-0.013 \\
(0.572) \\
\end{array}$ & $\begin{array}{r}-0.015 \\
(0.526) \\
\end{array}$ & $\begin{array}{r}-0.017 \\
(0.485) \\
\end{array}$ & $\begin{array}{r}-0.126 \\
(0.186) \\
\end{array}$ & $\begin{array}{r}-0.137 \\
(0.177) \\
\end{array}$ & $\begin{array}{r}-0.143 \\
(0.159) \\
\end{array}$ & $\begin{array}{r}-0.153 \\
(0.159) \\
\end{array}$ & $\begin{array}{r}-0.169 \\
(0.153) \\
\end{array}$ & $\begin{array}{r}-0.176 \\
(0.132) \\
\end{array}$ \\
\hline SIZE & $\begin{array}{r}0.004 \\
(0.468) \\
\end{array}$ & $\begin{array}{r}0.004 \\
(0.490) \\
\end{array}$ & $\begin{array}{r}0.004 \\
(0.453) \\
\end{array}$ & $\begin{array}{r}0.003 \\
(0.481) \\
\end{array}$ & $\begin{array}{r}0.003 \\
(0.529) \\
\end{array}$ & $\begin{array}{r}0.003 \\
(0.439) \\
\end{array}$ & $\begin{array}{r}-0.003 \\
(0.467) \\
\end{array}$ & $\begin{array}{r}-0.004 \\
(0.376) \\
\end{array}$ & $\begin{array}{r}-0.002 \\
(0.615) \\
\end{array}$ & $\begin{array}{r}-0.002 \\
(0.421) \\
\end{array}$ & $\begin{array}{r}-0.003 \\
(0.293) \\
\end{array}$ & $\begin{array}{r}0.000 \\
(0.972) \\
\end{array}$ \\
\hline$M T B$ & $\begin{array}{r}0.027 \\
(0.113) \\
\end{array}$ & $\begin{array}{r}0.027 \\
(0.116) \\
\end{array}$ & $\begin{array}{r}0.027 \\
(0.117) \\
\end{array}$ & $\begin{array}{r}0.016 \\
(0.294) \\
\end{array}$ & $\begin{array}{r}0.016 \\
(0.293) \\
\end{array}$ & $\begin{array}{r}0.017 \\
(0.291) \\
\end{array}$ & $\begin{array}{r}0.068 * * \\
(0.026) \\
\end{array}$ & $\begin{array}{r}0.066 * * \\
(0.031) \\
\end{array}$ & $\begin{array}{r}0.069 * * \\
(0.027)\end{array}$ & $\begin{array}{c}0.062 * \\
(0.086) \\
\end{array}$ & $\begin{array}{c}0.060 * \\
(0.094) \\
\end{array}$ & $\begin{array}{c}0.065^{*} \\
(0.086) \\
\end{array}$ \\
\hline$R O A$ & $\begin{array}{r}0.065 \\
(0.578) \\
\end{array}$ & $\begin{array}{r}0.069 \\
(0.557) \\
\end{array}$ & $\begin{array}{r}0.070 \\
(0.549) \\
\end{array}$ & $\begin{array}{r}0.435 * * \\
(0.024) \\
\end{array}$ & $\begin{array}{r}0.436^{* *} \\
(0.018)\end{array}$ & $\begin{array}{r}0.440 * * \\
(0.027) \\
\end{array}$ & $\begin{array}{r}1.332 * * \\
(0.033)\end{array}$ & $\begin{array}{r}1.348 * * \\
(0.025)\end{array}$ & $\begin{array}{r}1.340 * * \\
(0.033)\end{array}$ & $\begin{array}{r}1.929 * * \\
(0.045)\end{array}$ & $\begin{array}{r}1.943 * * \\
(0.035)\end{array}$ & $\begin{array}{r}1.946 * * \\
(0.049)\end{array}$ \\
\hline CFOGENDER & $\begin{array}{r}0.001 \\
(0.928) \\
\end{array}$ & $\begin{array}{r}0.002 \\
(0.733) \\
\end{array}$ & $\begin{array}{r}0.003 \\
(0.602) \\
\end{array}$ & $\begin{array}{r}0.011 \\
(0.423) \\
\end{array}$ & $\begin{array}{r}0.011 \\
(0.419) \\
\end{array}$ & $\begin{array}{r}0.014 \\
(0.286) \\
\end{array}$ & $\begin{array}{r}0.036 \\
(0.268) \\
\end{array}$ & $\begin{array}{r}0.038 \\
(0.236) \\
\end{array}$ & $\begin{array}{r}0.048 \\
(0.200) \\
\end{array}$ & $\begin{array}{r}0.014 \\
(0.636) \\
\end{array}$ & $\begin{array}{r}0.021 \\
(0.436) \\
\end{array}$ & $\begin{array}{r}0.029 \\
(0.388) \\
\end{array}$ \\
\hline $\begin{array}{l}\text { Observations } \\
\text { R-squared }\end{array}$ & $\begin{array}{r}771 \\
0.077\end{array}$ & $\begin{array}{r}771 \\
0.075\end{array}$ & $\begin{array}{r}771 \\
0.076\end{array}$ & $\begin{array}{r}800 \\
0.118\end{array}$ & $\begin{array}{r}800 \\
0.116\end{array}$ & $\begin{array}{r}800 \\
0.122\end{array}$ & $\begin{array}{r}764 \\
0.170\end{array}$ & $\begin{array}{r}764 \\
0.167\end{array}$ & $\begin{array}{r}764 \\
0.170\end{array}$ & $\begin{array}{r}783 \\
0.150\end{array}$ & $\begin{array}{r}783 \\
0.145\end{array}$ & $\begin{array}{r}783 \\
0.151\end{array}$ \\
\hline
\end{tabular}


WELCOME TO THE GRAY ZONE

TABLE 5 - continued

Perceived Honesty and Earnings Management

\begin{tabular}{|c|c|c|c|c|c|c|c|c|c|c|c|c|}
\hline Panel B & \multicolumn{3}{|c|}{$A B A C C$} & \multicolumn{3}{|c|}{ DICHEV } & \multicolumn{3}{|c|}{ REMI } & \multicolumn{3}{|c|}{ REM2 } \\
\hline CEOHONESTY & $\begin{array}{r}-0.024 \\
(0.106) \\
\end{array}$ & & & $\begin{array}{r}0.003 \\
(0.772) \\
\end{array}$ & & & $\begin{array}{r}-0.070 * * \\
(0.042) \\
\end{array}$ & & & $\begin{array}{r}-0.058 \\
(0.248) \\
\end{array}$ & & \\
\hline CEOTOPQ & & $\begin{array}{r}-0.019 * \\
(0.053)\end{array}$ & & & $\begin{array}{r}-0.006 \\
(0.561) \\
\end{array}$ & & & $\begin{array}{r}-0.054 \\
(0.130)\end{array}$ & & & $\begin{array}{r}-0.070 * * \\
(0.036) \\
\end{array}$ & \\
\hline СЕОВОТТОМQ & & & $\begin{array}{r}0.006 \\
(0.581) \\
\end{array}$ & & & $\begin{array}{r}0.009 * * \\
(0.034) \\
\end{array}$ & & & $\begin{array}{r}0.026 \\
(0.145) \\
\end{array}$ & & & $\begin{array}{r}0.011 \\
(0.595) \\
\end{array}$ \\
\hline СЕОSTOСКСОМР & $\begin{array}{r}0.048 \\
(0.132) \\
\end{array}$ & $\begin{array}{r}0.049 \\
(0.132) \\
\end{array}$ & $\begin{array}{r}0.048 \\
(0.130) \\
\end{array}$ & $\begin{array}{r}0.010 \\
(0.805) \\
\end{array}$ & $\begin{array}{r}0.011 \\
(0.794) \\
\end{array}$ & $\begin{array}{r}0.011 \\
(0.776) \\
\end{array}$ & $\begin{array}{r}0.106 \\
(0.502) \\
\end{array}$ & $\begin{array}{r}0.110 \\
(0.506) \\
\end{array}$ & $\begin{array}{r}0.107 \\
(0.484) \\
\end{array}$ & $\begin{array}{r}0.174 \\
(0.135) \\
\end{array}$ & $\begin{array}{r}0.180 \\
(0.146) \\
\end{array}$ & $\begin{array}{r}0.174 \\
(0.127) \\
\end{array}$ \\
\hline CEOBONUS & $\begin{array}{r}0.135 \\
(0.107) \\
\end{array}$ & $\begin{array}{r}0.136 \\
(0.120) \\
\end{array}$ & $\begin{array}{r}0.131 \\
(0.118) \\
\end{array}$ & $\begin{array}{r}-0.009 \\
(0.919) \\
\end{array}$ & $\begin{array}{r}-0.007 \\
(0.935) \\
\end{array}$ & $\begin{array}{r}-0.007 \\
(0.933) \\
\end{array}$ & $\begin{array}{r}-0.163 \\
(0.393) \\
\end{array}$ & $\begin{array}{r}-0.169 \\
(0.379) \\
\end{array}$ & $\begin{array}{r}-0.168 \\
(0.368) \\
\end{array}$ & $\begin{array}{r}-0.127 \\
(0.337) \\
\end{array}$ & $\begin{array}{r}-0.132 \\
(0.335) \\
\end{array}$ & $\begin{array}{r}-0.131 \\
(0.326) \\
\end{array}$ \\
\hline LOSS & $\begin{array}{r}-0.004 \\
(0.716) \\
\end{array}$ & $\begin{array}{r}-0.004 \\
(0.716) \\
\end{array}$ & $\begin{array}{r}-0.004 \\
(0.723) \\
\end{array}$ & $\begin{array}{r}0.056 * * * \\
(0.006) \\
\end{array}$ & $\begin{array}{r}0.056 * * * \\
(0.005)\end{array}$ & $\begin{array}{r}0.055^{*} * * \\
(0.004) \\
\end{array}$ & $\begin{array}{r}0.057 * \\
(0.051) \\
\end{array}$ & $\begin{array}{c}0.057 * * \\
(0.043)\end{array}$ & $\begin{array}{c}0.058 * \\
(0.051)\end{array}$ & $\begin{array}{r}0.084 * * \\
(0.024)\end{array}$ & $\begin{array}{r}0.083 * * \\
(0.046)\end{array}$ & $\begin{array}{r}0.085 * * \\
(0.018)\end{array}$ \\
\hline LEVERAGE & $\begin{array}{c}0.050 * \\
(0.074) \\
\end{array}$ & $\begin{array}{c}0.049 * \\
(0.095)\end{array}$ & $\begin{array}{c}0.052 * \\
(0.071) \\
\end{array}$ & $\begin{array}{r}0.023 \\
(0.119) \\
\end{array}$ & $\begin{array}{r}0.022 \\
(0.127) \\
\end{array}$ & $\begin{array}{r}0.023 \\
(0.104) \\
\end{array}$ & $\begin{array}{r}-0.120 * * \\
(0.049) \\
\end{array}$ & $\begin{array}{c}-0.120^{*} \\
(0.055)\end{array}$ & $\begin{array}{c}-0.117^{*} \\
(0.051)\end{array}$ & $\begin{array}{r}-0.028 \\
(0.148) \\
\end{array}$ & $\begin{array}{r}-0.028 \\
(0.158) \\
\end{array}$ & $\begin{array}{r}-0.026 \\
(0.167) \\
\end{array}$ \\
\hline SECTION302 & $\begin{array}{r}0.010 \\
(0.417) \\
\end{array}$ & $\begin{array}{r}0.009 \\
(0.445) \\
\end{array}$ & $\begin{array}{r}0.010 \\
(0.424) \\
\end{array}$ & $\begin{array}{r}0.016 \\
(0.181) \\
\end{array}$ & $\begin{array}{r}0.016 \\
(0.176) \\
\end{array}$ & $\begin{array}{r}0.016 \\
(0.174) \\
\end{array}$ & $\begin{array}{r}0.114^{* *} \\
(0.019) \\
\end{array}$ & $\begin{array}{r}0.112 * * \\
(0.023)\end{array}$ & $\begin{array}{r}0.115^{* *} * \\
(0.016)\end{array}$ & $\begin{array}{c}0.115^{*} \\
(0.079) \\
\end{array}$ & $\begin{array}{c}0.114^{*} \\
(0.087) \\
\end{array}$ & $\begin{array}{l}0.116^{*} \\
(0.076) \\
\end{array}$ \\
\hline PERCAUDITFEES & $\begin{array}{c}-0.092 * \\
(0.057)\end{array}$ & $\begin{array}{c}-0.085^{*} \\
(0.081)\end{array}$ & $\begin{array}{r}-0.091 * \\
(0.057)\end{array}$ & $\begin{array}{r}-0.025 \\
(0.304) \\
\end{array}$ & $\begin{array}{r}-0.025 \\
(0.265) \\
\end{array}$ & $\begin{array}{r}-0.027 \\
(0.267) \\
\end{array}$ & $\begin{array}{r}-0.197 \\
(0.119) \\
\end{array}$ & $\begin{array}{r}-0.186 \\
(0.139) \\
\end{array}$ & $\begin{array}{r}-0.194 \\
(0.114) \\
\end{array}$ & $\begin{array}{r}-0.227 \\
(0.130) \\
\end{array}$ & $\begin{array}{r}-0.216 \\
(0.155) \\
\end{array}$ & $\begin{array}{r}-0.223 \\
(0.124) \\
\end{array}$ \\
\hline$S I Z E$ & $\begin{array}{r}0.004 \\
(0.399) \\
\end{array}$ & $\begin{array}{r}0.004 \\
(0.385) \\
\end{array}$ & $\begin{array}{r}0.004 \\
(0.385) \\
\end{array}$ & $\begin{array}{r}0.005 \\
(0.335) \\
\end{array}$ & $\begin{array}{r}0.005 \\
(0.333) \\
\end{array}$ & $\begin{array}{r}0.005 \\
(0.334) \\
\end{array}$ & $\begin{array}{r}0.000 \\
(0.917) \\
\end{array}$ & $\begin{array}{r}0.001 \\
(0.812) \\
\end{array}$ & $\begin{array}{r}0.001 \\
(0.823) \\
\end{array}$ & $\begin{array}{r}0.003 \\
(0.282) \\
\end{array}$ & $\begin{array}{r}0.003 \\
(0.250) \\
\end{array}$ & $\begin{array}{r}0.003 \\
(0.270) \\
\end{array}$ \\
\hline$M T B$ & $\begin{array}{r}0.026 \\
(0.117)\end{array}$ & $\begin{array}{r}0.027 \\
(0.105)\end{array}$ & $\begin{array}{r}0.026 \\
(0.121)\end{array}$ & $\begin{array}{r}0.015 \\
(0.308)\end{array}$ & $\begin{array}{r}0.015 \\
(0.298)\end{array}$ & $\begin{array}{r}0.015 \\
(0.304)\end{array}$ & $\begin{array}{r}0.064 * * \\
(0.034)\end{array}$ & $\begin{array}{r}0.066^{* * *} \\
(0.028)\end{array}$ & $\begin{array}{r}0.064 * * \\
(0.035)\end{array}$ & $\begin{array}{r}0.057 \\
(0.104)\end{array}$ & $\begin{array}{c}0.060^{*} \\
(0.091)\end{array}$ & $\begin{array}{r}0.056 \\
(0.105)\end{array}$ \\
\hline$R O A$ & $\begin{array}{r}0.078 \\
(0.502)\end{array}$ & $\begin{array}{r}0.084 \\
(0.478)\end{array}$ & $\begin{array}{r}0.079 \\
(0.502)\end{array}$ & $\begin{array}{r}0.456^{* *} \\
(0.022)\end{array}$ & $\begin{array}{r}0.456^{* * *} \\
(0.022)\end{array}$ & $\begin{array}{r}0.453 * * \\
(0.024)\end{array}$ & $\begin{array}{r}1.460 * * \\
(0.016)\end{array}$ & $\begin{array}{r}1.476 * * \\
(0.014)\end{array}$ & $\begin{array}{r}1.460 * * \\
(0.017)\end{array}$ & $\begin{array}{r}2.084 * * \\
(0.029)\end{array}$ & $\begin{array}{r}2.105 * * \\
(0.026)\end{array}$ & $\begin{array}{r}2.086^{* * *} \\
(0.029)\end{array}$ \\
\hline CEOGENDER & $\begin{array}{r}-0.075^{*} \\
(0.094)\end{array}$ & $\begin{array}{c}-0.075^{*} \\
(0.085)\end{array}$ & $\begin{array}{c}-0.074 * \\
(0.100)\end{array}$ & $\begin{array}{r}-0.025 \\
(0.389)\end{array}$ & $\begin{array}{r}-0.026 \\
(0.381)\end{array}$ & $\begin{array}{r}-0.028 \\
(0.350)\end{array}$ & $\begin{array}{r}-0.244 * * \\
(0.022)\end{array}$ & $\begin{array}{r}-0.241^{* *} \\
(0.018)\end{array}$ & $\begin{array}{r}-0.242 * * \\
(0.025)\end{array}$ & $\begin{array}{r}-0.256^{*} \\
(0.060)\end{array}$ & $\begin{array}{r}-0.257 * \\
(0.050)\end{array}$ & $\begin{array}{l}-0.252^{*} \\
(0.063)\end{array}$ \\
\hline $\begin{array}{l}\text { Observations } \\
\text { R-squared }\end{array}$ & $\begin{array}{r}773 \\
0.090\end{array}$ & $\begin{array}{r}773 \\
0.093\end{array}$ & $\begin{array}{r}773 \\
0.088\end{array}$ & $\begin{array}{r}802 \\
0.106\end{array}$ & $\begin{array}{r}802 \\
0.106\end{array}$ & $\begin{array}{r}802 \\
0.107\end{array}$ & $\begin{array}{r}766 \\
0.174\end{array}$ & $\begin{array}{r}766 \\
0.177\end{array}$ & $\begin{array}{r}766 \\
0.173\end{array}$ & $\begin{array}{r}785 \\
0.150\end{array}$ & $\begin{array}{r}785 \\
0.154\end{array}$ & $\begin{array}{r}785 \\
0.149\end{array}$ \\
\hline
\end{tabular}




\section{WELCOME TO THE GRAY ZONE}

TABLE 5 - continued

\section{Perceived Honesty and Earnings Management}

\begin{tabular}{|c|c|c|c|c|c|c|c|c|c|c|c|c|}
\hline Panel C & \multicolumn{3}{|c|}{$A B A C C$} & \multicolumn{3}{|c|}{ DICHEV } & \multicolumn{3}{|c|}{ REMI } & \multicolumn{3}{|c|}{ REM2 } \\
\hline CFOHONESTY & $\begin{array}{r}-0.027 * * \\
(0.018)\end{array}$ & & & $\begin{array}{r}-0.048 * \\
(0.052)\end{array}$ & & & $\begin{array}{r}-0.152 * * \\
(0.013)\end{array}$ & & & $\begin{array}{r}-0.212 * * * \\
(0.000)\end{array}$ & & \\
\hline CEOHONESTY & $\begin{array}{r}-0.021 \\
(0.123)\end{array}$ & & & $\begin{array}{r}0.006 \\
(0.540)\end{array}$ & & & $\begin{array}{r}-0.057^{*} \\
(0.096)\end{array}$ & & & $\begin{array}{r}-0.040 \\
(0.354)\end{array}$ & & \\
\hline CFOTOPQ & & $\begin{array}{r}-0.006 \\
(0.260)\end{array}$ & & & $\begin{array}{r}-0.018 * * \\
(0.037)\end{array}$ & & & $\begin{array}{r}-0.054 * * \\
(0.024)\end{array}$ & & & $\begin{array}{r}-0.063^{* *} * \\
(0.031)\end{array}$ & \\
\hline CEOTOPQ & & $\begin{array}{l}-0.019 * \\
(0.055)\end{array}$ & & & $\begin{array}{r}-0.006 \\
(0.524) \\
\end{array}$ & & & $\begin{array}{r}-0.054 \\
(0.134) \\
\end{array}$ & & & $\begin{array}{r}-0.069^{*} \\
(0.050) \\
\end{array}$ & \\
\hline CFOBOTTOMQ & & & $\begin{array}{r}0.009 \\
(0.146) \\
\end{array}$ & & & $\begin{array}{l}0.025^{*} \\
(0.075)\end{array}$ & & & $\begin{array}{r}0.069 * * \\
(0.015)\end{array}$ & & & $\begin{array}{r}0.106 * * \\
(0.027) \\
\end{array}$ \\
\hline CEOBOTTOMQ & & & $\begin{array}{r}0.004 \\
(0.660)\end{array}$ & & & $\begin{array}{l}0.006^{*} \\
(0.095)\end{array}$ & & & $\begin{array}{r}0.017 \\
(0.237)\end{array}$ & & & $\begin{array}{r}-0.002 \\
(0.912)\end{array}$ \\
\hline AVERSTOCKCOMP & $\begin{array}{r}0.074 \\
(0.122) \\
\end{array}$ & $\begin{array}{r}0.076 \\
(0.111) \\
\end{array}$ & $\begin{array}{r}0.078 \\
(0.109) \\
\end{array}$ & $\begin{array}{r}0.046 \\
(0.344) \\
\end{array}$ & $\begin{array}{r}0.042 \\
(0.382) \\
\end{array}$ & $\begin{array}{r}0.052 \\
(0.292) \\
\end{array}$ & $\begin{array}{r}0.225 \\
(0.256) \\
\end{array}$ & $\begin{array}{r}0.220 \\
(0.277) \\
\end{array}$ & $\begin{array}{r}0.249 \\
(0.200) \\
\end{array}$ & $\begin{array}{l}0.305^{*} \\
(0.070) \\
\end{array}$ & $\begin{array}{l}0.298 * \\
(0.078) \\
\end{array}$ & $\begin{array}{r}0.339 * * \\
(0.042) \\
\end{array}$ \\
\hline$A V E R B O N U S$ & $\begin{array}{r}0.152 \\
(0.171) \\
\end{array}$ & $\begin{array}{r}0.161 \\
(0.161) \\
\end{array}$ & $\begin{array}{r}0.152 \\
(0.176) \\
\end{array}$ & $\begin{array}{r}0.033 \\
(0.707) \\
\end{array}$ & $\begin{array}{r}0.037 \\
(0.681) \\
\end{array}$ & $\begin{array}{r}0.035 \\
(0.687) \\
\end{array}$ & $\begin{array}{r}-0.082 \\
(0.682) \\
\end{array}$ & $\begin{array}{r}-0.078 \\
(0.692) \\
\end{array}$ & $\begin{array}{r}-0.066 \\
(0.732) \\
\end{array}$ & $\begin{array}{r}-0.022 \\
(0.867) \\
\end{array}$ & $\begin{array}{r}-0.015 \\
(0.906) \\
\end{array}$ & $\begin{array}{r}0.001 \\
(0.993) \\
\end{array}$ \\
\hline LOSS & $\begin{array}{r}-0.005 \\
(0.705)\end{array}$ & $\begin{array}{r}-0.004 \\
(0.729)\end{array}$ & $\begin{array}{r}-0.004 \\
(0.734)\end{array}$ & $\begin{array}{r}0.059 * * \\
(0.011)\end{array}$ & $\begin{array}{r}0.058 * * \\
(0.011) \\
\end{array}$ & $\begin{array}{r}0.058 * * * \\
(0.008) \\
\end{array}$ & $\begin{array}{l}0.065^{*} \\
(0.055)\end{array}$ & $\begin{array}{r}0.067 * * \\
(0.040)\end{array}$ & $\begin{array}{l}0.064^{*} \\
(0.062)\end{array}$ & $\begin{array}{r}0.086 * * \\
(0.022)\end{array}$ & $\begin{array}{r}0.087 * * \\
(0.024)\end{array}$ & $\begin{array}{r}0.085^{* *} \\
(0.040)\end{array}$ \\
\hline LEVERAGE & $\begin{array}{l}0.054^{*} \\
(0.057) \\
\end{array}$ & $\begin{array}{l}0.051^{*} \\
(0.082) \\
\end{array}$ & $\begin{array}{c}0.057^{*} \\
(0.051) \\
\end{array}$ & $\begin{array}{c}0.024^{*} \\
(0.079) \\
\end{array}$ & $\begin{array}{r}0.020 \\
(0.137) \\
\end{array}$ & $\begin{array}{r}0.029 * \\
(0.064) \\
\end{array}$ & $\begin{array}{r}-0.116^{*} \\
(0.052) \\
\end{array}$ & $\begin{array}{r}-0.126^{*} \\
(0.051) \\
\end{array}$ & $\begin{array}{r}-0.100^{*} \\
(0.070) \\
\end{array}$ & $\begin{array}{r}-0.018 \\
(0.396) \\
\end{array}$ & $\begin{array}{r}-0.033 \\
(0.193) \\
\end{array}$ & $\begin{array}{r}0.004 \\
(0.849) \\
\end{array}$ \\
\hline SECTION3O2 & $\begin{array}{r}0.011 \\
(0.348)\end{array}$ & $\begin{array}{r}0.010 \\
(0.378)\end{array}$ & $\begin{array}{r}0.011 \\
(0.370)\end{array}$ & $\begin{array}{r}0.017 \\
(0.197)\end{array}$ & $\begin{array}{r}0.017 \\
(0.209)\end{array}$ & $\begin{array}{r}0.018 \\
(0.171)\end{array}$ & $\begin{array}{r}0.117 * * \\
(0.014)\end{array}$ & $\begin{array}{r}0.114 * * \\
(0.015)\end{array}$ & $\begin{array}{r}0.118 * * \\
(0.015)\end{array}$ & $\begin{array}{l}0.118^{*} \\
(0.065)\end{array}$ & $\begin{array}{c}0.115^{*} \\
(0.070)\end{array}$ & $\begin{array}{c}0.119 * \\
(0.069)\end{array}$ \\
\hline PERCAUDITFEES & $\begin{array}{l}-0.087^{*} \\
(0.060) \\
\end{array}$ & $\begin{array}{r}-0.083^{*} \\
(0.093) \\
\end{array}$ & $\begin{array}{l}-0.090 * \\
(0.055) \\
\end{array}$ & $\begin{array}{r}-0.014 \\
(0.567) \\
\end{array}$ & $\begin{array}{r}-0.016 \\
(0.479) \\
\end{array}$ & $\begin{array}{r}-0.020 \\
(0.437) \\
\end{array}$ & $\begin{array}{r}-0.150 \\
(0.160) \\
\end{array}$ & $\begin{array}{r}-0.150 \\
(0.176) \\
\end{array}$ & $\begin{array}{r}-0.163 \\
(0.138) \\
\end{array}$ & $\begin{array}{r}-0.174 \\
(0.151) \\
\end{array}$ & $\begin{array}{r}-0.180 \\
(0.176) \\
\end{array}$ & $\begin{array}{r}-0.191 \\
(0.124) \\
\end{array}$ \\
\hline SIZE & $\begin{array}{r}0.003 \\
(0.487) \\
\end{array}$ & $\begin{array}{r}0.003 \\
(0.498) \\
\end{array}$ & $\begin{array}{r}0.004 \\
(0.455) \\
\end{array}$ & $\begin{array}{r}0.004 \\
(0.405) \\
\end{array}$ & $\begin{array}{r}0.003 \\
(0.458) \\
\end{array}$ & $\begin{array}{r}0.004 \\
(0.364) \\
\end{array}$ & $\begin{array}{r}-0.002 \\
(0.641) \\
\end{array}$ & $\begin{array}{r}-0.003 \\
(0.540) \\
\end{array}$ & $\begin{array}{r}-0.001 \\
(0.888) \\
\end{array}$ & $\begin{array}{r}-0.001 \\
(0.604) \\
\end{array}$ & $\begin{array}{r}-0.002 \\
(0.353) \\
\end{array}$ & $\begin{array}{r}0.001 \\
(0.504) \\
\end{array}$ \\
\hline$M T B$ & $\begin{array}{r}0.027 \\
(0.116) \\
\end{array}$ & $\begin{array}{r}0.027 \\
(0.106) \\
\end{array}$ & $\begin{array}{r}0.027 \\
(0.123) \\
\end{array}$ & $\begin{array}{r}0.016 \\
(0.299) \\
\end{array}$ & $\begin{array}{r}0.016 \\
(0.288) \\
\end{array}$ & $\begin{array}{r}0.016 \\
(0.292) \\
\end{array}$ & $\begin{array}{r}0.067 * * \\
(0.030) \\
\end{array}$ & $\begin{array}{r}0.067 * * \\
(0.028) \\
\end{array}$ & $\begin{array}{r}0.067 * * \\
(0.032) \\
\end{array}$ & $\begin{array}{c}0.061^{*} \\
(0.098)\end{array}$ & $\begin{array}{c}0.061 * \\
(0.093) \\
\end{array}$ & $\begin{array}{c}0.062 * \\
(0.097) \\
\end{array}$ \\
\hline$R O A$ & $\begin{array}{r}0.072 \\
(0.563) \\
\end{array}$ & $\begin{array}{r}0.080 \\
(0.522) \\
\end{array}$ & $\begin{array}{r}0.077 \\
(0.538) \\
\end{array}$ & $\begin{array}{r}0.445 * * \\
(0.024) \\
\end{array}$ & $\begin{array}{r}.446 * * \\
(0.017) \\
\end{array}$ & $\begin{array}{r}0.449 * * \\
(0.027) \\
\end{array}$ & $\begin{array}{r}1.396 * * \\
(0.034) \\
\end{array}$ & $\begin{array}{r}1.424 * * \\
(0.023) \\
\end{array}$ & $\begin{array}{r}1.407 * * \\
(0.034) \\
\end{array}$ & $\begin{array}{r}1.995 * * \\
(0.045) \\
\end{array}$ & $\begin{array}{r}2.025 * * \\
(0.032) \\
\end{array}$ & $\begin{array}{r}2.017 * * \\
(0.048) \\
\end{array}$ \\
\hline CFOGENDER & $\begin{array}{r}0.004 \\
(0.687) \\
\end{array}$ & $\begin{array}{r}0.006 \\
(0.570) \\
\end{array}$ & $\begin{array}{r}0.005 \\
(0.557) \\
\end{array}$ & $\begin{array}{r}0.012 \\
(0.430) \\
\end{array}$ & $\begin{array}{r}0.012 \\
(0.416) \\
\end{array}$ & $\begin{array}{r}0.014 \\
(0.318) \\
\end{array}$ & $\begin{array}{r}0.045 \\
(0.271) \\
\end{array}$ & $\begin{array}{r}0.048 \\
(0.239) \\
\end{array}$ & $\begin{array}{r}0.054 \\
(0.224) \\
\end{array}$ & $\begin{array}{r}0.023 \\
(0.570)\end{array}$ & $\begin{array}{r}0.032 \\
(0.420) \\
\end{array}$ & $\begin{array}{r}0.037 \\
(0.386) \\
\end{array}$ \\
\hline CEOGENDER & $\begin{array}{r}-0.073 \\
(0.112) \\
\end{array}$ & $\begin{array}{r}-0.074^{*} \\
(0.097) \\
\end{array}$ & $\begin{array}{r}-0.073 \\
(0.115) \\
\end{array}$ & $\begin{array}{r}-0.023 \\
(0.381) \\
\end{array}$ & $\begin{array}{r}-0.026 \\
(0.363) \\
\end{array}$ & $\begin{array}{r}-0.026 \\
(0.339) \\
\end{array}$ & $\begin{array}{r}-0.236^{* *} \\
(0.039) \\
\end{array}$ & $\begin{array}{r}-0.240^{* *} \\
(0.030) \\
\end{array}$ & $\begin{array}{r}-0.235^{* *} \\
(0.040) \\
\end{array}$ & $\begin{array}{c}-0.244^{*} \\
(0.091) \\
\end{array}$ & $\begin{array}{r}-0.254^{*} \\
(0.065) \\
\end{array}$ & $\begin{array}{r}-0.240^{*} \\
(0.091) \\
\end{array}$ \\
\hline Observations & 770 & 770 & 770 & 799 & 799 & 799 & 763 & 763 & 763 & 782 & 782 & 782 \\
\hline R-squared & 0.094 & 0.096 & 0.091 & 0.119 & 0.117 & 0.122 & 0.186 & 0.187 & 0.185 & 0.161 & 0.161 & 0.163 \\
\hline
\end{tabular}




\section{TABLE 6}

\section{Interaction between CFO and CEO perceived honesty and earnings management}

This table reports the OLS regression results of earnings management on the interaction between perceived CFO honesty and CEO honesty. Variable definitions are provided in Appendix A. ***, **, and * denote statistical significance at 1\%, 5\%, and $10 \%$ levels, respectively.

\begin{tabular}{|c|c|c|c|c|c|c|c|c|c|c|c|c|}
\hline & \multicolumn{3}{|c|}{$A B A C C$} & \multicolumn{3}{|c|}{ DICHEV } & \multicolumn{3}{|c|}{ REMI } & \multicolumn{3}{|c|}{ REM2 } \\
\hline $\mathrm{CFO}+\mathrm{CEO}+\mathrm{CFO} * \mathrm{CEO}$ & $\begin{array}{r}-0.054^{*} \\
(0.092) \\
\end{array}$ & & & $\begin{array}{r}-0.037 \\
(0.116) \\
\end{array}$ & & & $\begin{array}{r}-0.216^{* * *} * \\
(0.000) \\
\end{array}$ & & & $\begin{array}{r}-0.266^{* * * *} \\
(0.009) \\
\end{array}$ & & \\
\hline$T O P Q / T O P Q$ & & $\begin{array}{r}-0.030 * * \\
(0.032) \\
\end{array}$ & & & $\begin{array}{r}-0.033 * \\
(0.053) \\
\end{array}$ & & & $\begin{array}{r}-0.136 * * * \\
(0.005)\end{array}$ & & & $\begin{array}{r}-0.181 * * * \\
(0.005) \\
\end{array}$ & \\
\hline ВОТTOMQ/ВОTТОМQ & & & $\begin{array}{r}0.007 \\
(0.299) \\
\end{array}$ & & & $\begin{array}{r}0.029 * * \\
(0.041) \\
\end{array}$ & & & $\begin{array}{r}0.073^{*} \\
(0.069) \\
\end{array}$ & & & $\begin{array}{r}0.053 \\
(0.261) \\
\end{array}$ \\
\hline AVERSTOCKCOMP & $\begin{array}{r}0.073 \\
(0.125) \\
\end{array}$ & $\begin{array}{r}0.075 \\
(0.111) \\
\end{array}$ & $\begin{array}{r}0.077 \\
(0.123) \\
\end{array}$ & $\begin{array}{r}0.043 \\
(0.361) \\
\end{array}$ & $\begin{array}{r}0.041 \\
(0.395) \\
\end{array}$ & $\begin{array}{r}0.051 \\
(0.307) \\
\end{array}$ & $\begin{array}{r}0.219 \\
(0.268) \\
\end{array}$ & $\begin{array}{r}0.218 \\
(0.282) \\
\end{array}$ & $\begin{array}{r}0.247 \\
(0.205) \\
\end{array}$ & $\begin{array}{c}0.292 * \\
(0.076)\end{array}$ & $\begin{array}{c}0.294^{*} \\
(0.083)\end{array}$ & $\begin{array}{c}0.329 * \\
(0.051)\end{array}$ \\
\hline$A V E R B O N U S$ & $\begin{array}{r}0.152 \\
(0.173) \\
\end{array}$ & $\begin{array}{r}0.162 \\
(0.153) \\
\end{array}$ & $\begin{array}{r}0.153 \\
(0.174) \\
\end{array}$ & $\begin{array}{r}0.037 \\
(0.673) \\
\end{array}$ & $\begin{array}{r}0.037 \\
(0.673) \\
\end{array}$ & $\begin{array}{r}0.034 \\
(0.694) \\
\end{array}$ & $\begin{array}{r}-0.078 \\
(0.692) \\
\end{array}$ & $\begin{array}{r}-0.071 \\
(0.705) \\
\end{array}$ & $\begin{array}{r}-0.065 \\
(0.742) \\
\end{array}$ & $\begin{array}{r}-0.022 \\
(0.866) \\
\end{array}$ & $\begin{array}{r}-0.007 \\
(0.952) \\
\end{array}$ & $\begin{array}{r}0.002 \\
(0.988) \\
\end{array}$ \\
\hline$L O S S$ & $\begin{array}{r}-0.005 \\
(0.664) \\
\end{array}$ & $\begin{array}{r}-0.005 \\
(0.679) \\
\end{array}$ & $\begin{array}{r}-0.004 \\
(0.782) \\
\end{array}$ & $\begin{array}{r}0.059 * * * \\
(0.009) \\
\end{array}$ & $\begin{array}{r}0.058 * * \\
(0.012) \\
\end{array}$ & $\begin{array}{r}0.058 * * * \\
(0.009) \\
\end{array}$ & $\begin{array}{r}0.064 * \\
(0.068) \\
\end{array}$ & $\begin{array}{c}0.064 * \\
(0.066) \\
\end{array}$ & $\begin{array}{r}0.065^{*} \\
(0.064) \\
\end{array}$ & $\begin{array}{r}0.084 * * \\
(0.019) \\
\end{array}$ & $\begin{array}{r}0.082 * * \\
(0.013) \\
\end{array}$ & $\begin{array}{r}0.088 * * \\
(0.034) \\
\end{array}$ \\
\hline LEVERAGE & $\begin{array}{c}0.055^{*} \\
(0.059)\end{array}$ & $\begin{array}{c}0.052 * \\
(0.086)\end{array}$ & $\begin{array}{c}0.057 * \\
(0.055)\end{array}$ & $\begin{array}{c}0.023 * \\
(0.087) \\
\end{array}$ & $\begin{array}{r}0.022 \\
(0.145) \\
\end{array}$ & $\begin{array}{r}0.029 * \\
(0.064) \\
\end{array}$ & $\begin{array}{c}-0.113 * \\
(0.055)\end{array}$ & $\begin{array}{r}-0.120 * * \\
(0.048) \\
\end{array}$ & $\begin{array}{c}-0.099 * \\
(0.073)\end{array}$ & $\begin{array}{r}-0.017 \\
(0.375)\end{array}$ & $\begin{array}{r}-0.022 \\
(0.307) \\
\end{array}$ & $\begin{array}{r}0.006 \\
(0.775) \\
\end{array}$ \\
\hline SECTION302 & $\begin{array}{r}0.010 \\
(0.361) \\
\end{array}$ & $\begin{array}{r}0.009 \\
(0.390) \\
\end{array}$ & $\begin{array}{r}0.010 \\
(0.335) \\
\end{array}$ & $\begin{array}{r}0.017 \\
(0.185) \\
\end{array}$ & $\begin{array}{r}0.016 \\
(0.217) \\
\end{array}$ & $\begin{array}{r}0.018 \\
(0.179) \\
\end{array}$ & $\begin{array}{r}0.115^{* *} \\
(0.016) \\
\end{array}$ & $\begin{array}{r}0.110 * * \\
(0.015) \\
\end{array}$ & $\begin{array}{r}0.118 * * \\
(0.015) \\
\end{array}$ & $\begin{array}{r}0.115^{*} \\
(0.073) \\
\end{array}$ & $\begin{array}{c}0.108 * \\
(0.081) \\
\end{array}$ & $\begin{array}{r}0.117 * \\
(0.071) \\
\end{array}$ \\
\hline PERCAUDITFEES & $\begin{array}{r}-0.088^{*} \\
(0.062)\end{array}$ & $\begin{array}{r}-0.083^{*} \\
(0.094)\end{array}$ & $\begin{array}{c}-0.090 * \\
(0.056)\end{array}$ & $\begin{array}{r}-0.020 \\
(0.395)\end{array}$ & $\begin{array}{r}-0.014 \\
(0.526)\end{array}$ & $\begin{array}{r}-0.020 \\
(0.445)\end{array}$ & $\begin{array}{r}-0.163 \\
(0.142)\end{array}$ & $\begin{array}{r}-0.147 \\
(0.182)\end{array}$ & $\begin{array}{c}-0.162 \\
(0.140)\end{array}$ & $\begin{array}{r}-0.196 \\
(0.140)\end{array}$ & $\begin{array}{r}-0.174 \\
(0.187)\end{array}$ & $\begin{array}{r}-0.189 \\
(0.128)\end{array}$ \\
\hline$S I Z E$ & $\begin{array}{r}0.004 \\
(0.465) \\
\end{array}$ & $\begin{array}{r}0.003 \\
(0.482) \\
\end{array}$ & $\begin{array}{r}0.004 \\
(0.428) \\
\end{array}$ & $\begin{array}{r}0.004 \\
(0.411) \\
\end{array}$ & $\begin{array}{r}0.004 \\
(0.446) \\
\end{array}$ & $\begin{array}{r}0.004 \\
(0.367) \\
\end{array}$ & $\begin{array}{r}-0.002 \\
(0.682) \\
\end{array}$ & $\begin{array}{r}-0.002 \\
(0.625) \\
\end{array}$ & $\begin{array}{r}-0.000 \\
(0.964) \\
\end{array}$ & $\begin{array}{r}-0.001 \\
(0.772) \\
\end{array}$ & $\begin{array}{r}-0.001 \\
(0.622) \\
\end{array}$ & $\begin{array}{r}0.003 \\
(0.132) \\
\end{array}$ \\
\hline$M T B$ & $\begin{array}{r}0.027 \\
(0.112)\end{array}$ & $\begin{array}{r}0.027 \\
(0.107)\end{array}$ & $\begin{array}{r}0.027 \\
(0.128)\end{array}$ & $\begin{array}{r}0.016 \\
(0.290)\end{array}$ & $\begin{array}{r}0.016 \\
(0.286)\end{array}$ & $\begin{array}{r}0.017 \\
(0.293) \\
\end{array}$ & $\begin{array}{r}0.069 * * \\
(0.023)\end{array}$ & $\begin{array}{r}0.068 * * \\
(0.027)\end{array}$ & $\begin{array}{r}0.068 * * \\
(0.032)\end{array}$ & $\begin{array}{c}0.063 * \\
(0.083)\end{array}$ & $\begin{array}{c}0.063 * \\
(0.088)\end{array}$ & $\begin{array}{c}0.064 * \\
(0.093)\end{array}$ \\
\hline$R O A$ & $\begin{array}{r}0.069 \\
(0.581)\end{array}$ & $\begin{array}{r}0.077 \\
(0.536)\end{array}$ & $\begin{array}{r}0.078 \\
(0.539)\end{array}$ & $\begin{array}{r}0.445 * * \\
(0.023)\end{array}$ & $\begin{array}{r}0.442 * * \\
(0.018)\end{array}$ & $\begin{array}{r}0.449 * * \\
(0.028)\end{array}$ & $\begin{array}{r}1.384 * * \\
(0.034)\end{array}$ & $\begin{array}{r}1.409 * * \\
(0.024)\end{array}$ & $\begin{array}{r}1.408 * * \\
(0.035)\end{array}$ & $\begin{array}{r}1.986 * * \\
(0.044)\end{array}$ & $\begin{array}{r}1.999 * * \\
(0.032)\end{array}$ & $\begin{array}{r}2.015 * * \\
(0.050)\end{array}$ \\
\hline CFOGENDER & $\begin{array}{r}0.004 \\
(0.633)\end{array}$ & $\begin{array}{r}0.006 \\
(0.581)\end{array}$ & $\begin{array}{r}0.005 \\
(0.560)\end{array}$ & $\begin{array}{r}0.016 \\
(0.305)\end{array}$ & $\begin{array}{r}0.012 \\
(0.427)\end{array}$ & $\begin{array}{r}0.014 \\
(0.316)\end{array}$ & $\begin{array}{r}0.054 \\
(0.239)\end{array}$ & $\begin{array}{r}0.048 \\
(0.252)\end{array}$ & $\begin{array}{r}0.053 \\
(0.230)\end{array}$ & $\begin{array}{r}0.038 \\
(0.399)\end{array}$ & $\begin{array}{r}0.031 \\
(0.452)\end{array}$ & $\begin{array}{r}0.034 \\
(0.417)\end{array}$ \\
\hline CEOGENDER & $\begin{array}{r}-0.073 \\
(0.111) \\
\end{array}$ & $\begin{array}{c}-0.073^{*} \\
(0.097)\end{array}$ & $\begin{array}{r}-0.072 \\
(0.112) \\
\end{array}$ & $\begin{array}{r}-0.027 \\
(0.350)\end{array}$ & $\begin{array}{r}-0.025 \\
(0.363) \\
\end{array}$ & $\begin{array}{r}-0.025 \\
(0.343)\end{array}$ & $\begin{array}{r}-0.242 * * \\
(0.036)\end{array}$ & $\begin{array}{r}-0.237 * * \\
(0.032)\end{array}$ & $\begin{array}{r}-0.234 * * \\
(0.042)\end{array}$ & $\begin{array}{c}-0.255^{*} \\
(0.073)\end{array}$ & $\begin{array}{c}-0.249 * \\
(0.071)\end{array}$ & $\begin{array}{r}-0.236 \\
(0.100)\end{array}$ \\
\hline Observations & 770 & 770 & 770 & 799 & 799 & 799 & 763 & 763 & 763 & 782 & 782 & 782 \\
\hline R-squared & 0.096 & 0.096 & 0.092 & 0.113 & 0.118 & 0.123 & 0.187 & 0.188 & 0.186 & 0.161 & 0.163 & 0.165 \\
\hline
\end{tabular}




\section{WELCOME TO THE GRAY ZONE}

Table 7

\section{Perceived CEO honesty, CEO power and earnings management}

This table reports the OLS regression results of earnings management on the interaction between perceived CEO honesty and CEO power. Variable definitions are provided in Appendix A. ***, **, and * denote statistical significance at 1\%, 5\%, and $10 \%$ levels, respectively.

\begin{tabular}{|c|c|c|c|c|c|c|c|c|c|c|c|c|}
\hline & \multicolumn{3}{|c|}{$A B A C C$} & \multicolumn{3}{|c|}{ DICHEV } & \multicolumn{3}{|c|}{ REMI } & \multicolumn{3}{|c|}{ REM2 } \\
\hline $\begin{array}{l}\text { HONESTY+POWER } \\
+H O N E S T Y * P O W E R\end{array}$ & $\begin{array}{r}-0.028 \\
(0.160)\end{array}$ & & & $\begin{array}{c}-0.025^{*} \\
(0.058)\end{array}$ & & & $\begin{array}{r}-0.089 \\
(0.136)\end{array}$ & & & $\begin{array}{r}-0.119 \\
(0.235)\end{array}$ & & \\
\hline TOPQ/POWER & & $\begin{array}{r}-0.026 \\
(0.131)\end{array}$ & & & $\begin{array}{r}-0.030 * * \\
(0.017)\end{array}$ & & & $\begin{array}{r}-0.085^{* *} \\
(0.015)\end{array}$ & & & $\begin{array}{r}-0.145^{* *} * \\
(0.025)\end{array}$ & \\
\hline BOTTOMQ/POWER & & & $\begin{array}{r}-0.001 \\
(0.955)\end{array}$ & & & $\begin{array}{r}0.014 \\
(0.234)\end{array}$ & & & $\begin{array}{l}0.051 * \\
(0.083)\end{array}$ & & & $\begin{array}{r}0.031 \\
(0.434)\end{array}$ \\
\hline СЕOSTOCКСОМР & $\begin{array}{r}0.036 \\
(0.135)\end{array}$ & $\begin{array}{r}0.037 \\
(0.134)\end{array}$ & $\begin{array}{r}0.035 \\
(0.111)\end{array}$ & $\begin{array}{r}0.001 \\
(0.986)\end{array}$ & $\begin{array}{r}0.006 \\
(0.886)\end{array}$ & $\begin{array}{r}0.005 \\
(0.909)\end{array}$ & $\begin{array}{r}0.159 \\
(0.235)\end{array}$ & $\begin{array}{r}0.172 \\
(0.221)\end{array}$ & $\begin{array}{r}0.167 \\
(0.189)\end{array}$ & $\begin{array}{l}0.210 * \\
(0.051)\end{array}$ & $\begin{array}{l}0.230^{*} \\
(0.052)\end{array}$ & $\begin{array}{r}0.220 * * \\
(0.032)\end{array}$ \\
\hline CEOBONUS & $\begin{array}{r}0.149 \\
(0.151)\end{array}$ & $\begin{array}{r}0.146 \\
(0.154)\end{array}$ & $\begin{array}{r}0.137 \\
(0.169)\end{array}$ & $\begin{array}{r}-0.026 \\
(0.791)\end{array}$ & $\begin{array}{r}-0.023 \\
(0.822)\end{array}$ & $\begin{array}{r}-0.011 \\
(0.915)\end{array}$ & $\begin{array}{r}-0.053 \\
(0.722)\end{array}$ & $\begin{array}{r}-0.067 \\
(0.651)\end{array}$ & $\begin{array}{r}-0.038 \\
(0.775)\end{array}$ & $\begin{array}{r}-0.038 \\
(0.713)\end{array}$ & $\begin{array}{r}-0.043 \\
(0.679)\end{array}$ & $\begin{array}{r}-0.010 \\
(0.921)\end{array}$ \\
\hline LOSS & $\begin{array}{r}-0.018 \\
(0.120)\end{array}$ & $\begin{array}{r}-0.018 \\
(0.133)\end{array}$ & $\begin{array}{r}-0.019 \\
(0.132)\end{array}$ & $\begin{array}{r}0.046 * * * \\
(0.002)\end{array}$ & $\begin{array}{r}0.045^{* * * *} \\
(0.004)\end{array}$ & $\begin{array}{r}0.048 * * * \\
(0.004)\end{array}$ & $\begin{array}{r}0.043 \\
(0.229)\end{array}$ & $\begin{array}{r}0.040 \\
(0.263)\end{array}$ & $\begin{array}{r}0.046 \\
(0.193)\end{array}$ & $\begin{array}{r}0.057 \\
(0.345)\end{array}$ & $\begin{array}{r}0.056 \\
(0.343)\end{array}$ & $\begin{array}{r}0.066 \\
(0.283)\end{array}$ \\
\hline LEVERAGE & $\begin{array}{l}0.056^{*} \\
(0.077)\end{array}$ & $\begin{array}{r}0.058 \\
(0.101)\end{array}$ & $\begin{array}{c}0.063^{*} \\
(0.084)\end{array}$ & $\begin{array}{r}0.035 \\
(0.212)\end{array}$ & $\begin{array}{r}0.029 \\
(0.289)\end{array}$ & $\begin{array}{r}0.027 \\
(0.321)\end{array}$ & $\begin{array}{r}-0.102 \\
(0.112)\end{array}$ & $\begin{array}{r}-0.111 \\
(0.104)\end{array}$ & $\begin{array}{r}-0.112 * \\
(0.081)\end{array}$ & $\begin{array}{r}-0.005 \\
(0.859)\end{array}$ & $\begin{array}{r}-0.020 \\
(0.532)\end{array}$ & $\begin{array}{l}-0.027 \\
(0.452)\end{array}$ \\
\hline SECTION302 & $\begin{array}{r}0.009 \\
(0.370)\end{array}$ & $\begin{array}{r}0.007 \\
(0.430)\end{array}$ & $\begin{array}{r}0.009 \\
(0.407)\end{array}$ & $\begin{array}{r}0.017 \\
(0.224)\end{array}$ & $\begin{array}{r}0.019 \\
(0.177)\end{array}$ & $\begin{array}{r}0.018 \\
(0.202)\end{array}$ & $\begin{array}{r}0.124 * * \\
(0.040)\end{array}$ & $\begin{array}{r}0.126 * * \\
(0.036)\end{array}$ & $\begin{array}{r}0.127 * * \\
(0.032)\end{array}$ & $\begin{array}{l}0.136 * \\
(0.058)\end{array}$ & $\begin{array}{l}0.139 * \\
(0.052)\end{array}$ & $\begin{array}{l}0.136^{*} \\
(0.050)\end{array}$ \\
\hline PERCAUDITFEES & $\begin{array}{r}-0.095^{*} \\
(0.096)\end{array}$ & $\begin{array}{r}-0.092 \\
(0.103)\end{array}$ & $\begin{array}{r}-0.096^{*} \\
(0.084)\end{array}$ & $\begin{array}{l}-0.032 \\
(0.208)\end{array}$ & $\begin{array}{r}-0.030 \\
(0.198)\end{array}$ & $\begin{array}{l}-0.029 \\
(0.251)\end{array}$ & $\begin{array}{r}-0.177 \\
(0.220)\end{array}$ & $\begin{array}{r}-0.172 \\
(0.228)\end{array}$ & $\begin{array}{r}-0.167 \\
(0.212)\end{array}$ & $\begin{array}{r}-0.238 \\
(0.217)\end{array}$ & $\begin{array}{l}-0.234 \\
(0.226)\end{array}$ & $\begin{array}{r}-0.218 \\
(0.215)\end{array}$ \\
\hline SIZE & $\begin{array}{r}0.004 \\
(0.327)\end{array}$ & $\begin{array}{r}0.004 \\
(0.290)\end{array}$ & $\begin{array}{r}0.004 \\
(0.324)\end{array}$ & $\begin{array}{r}0.006 \\
(0.339)\end{array}$ & $\begin{array}{r}0.006 \\
(0.322)\end{array}$ & $\begin{array}{r}0.006 \\
(0.340)\end{array}$ & $\begin{array}{r}0.004 \\
(0.611)\end{array}$ & $\begin{array}{r}0.005 \\
(0.494)\end{array}$ & $\begin{array}{r}0.004 \\
(0.586)\end{array}$ & $\begin{array}{r}0.003 \\
(0.658)\end{array}$ & $\begin{array}{r}0.004 \\
(0.549)\end{array}$ & $\begin{array}{r}0.004 \\
(0.592)\end{array}$ \\
\hline$M T B$ & $\begin{array}{l}0.025 * \\
(0.099)\end{array}$ & $\begin{array}{l}0.026 * \\
(0.084)\end{array}$ & $\begin{array}{l}0.025 * \\
(0.090)\end{array}$ & $\begin{array}{r}0.016 \\
(0.242)\end{array}$ & $\begin{array}{r}0.017 \\
(0.217)\end{array}$ & $\begin{array}{r}0.016 \\
(0.265)\end{array}$ & $\begin{array}{r}0.069 * * \\
(0.031)\end{array}$ & $\begin{array}{r}0.070 * * \\
(0.031)\end{array}$ & $\begin{array}{r}0.066^{* *} \\
(0.028)\end{array}$ & $\begin{array}{r}0.057 \\
(0.119)\end{array}$ & $\begin{array}{c}0.060 * \\
(0.098)\end{array}$ & $\begin{array}{r}0.052 \\
(0.126)\end{array}$ \\
\hline$R O A$ & $\begin{array}{r}0.080 \\
(0.468)\end{array}$ & $\begin{array}{r}0.095 \\
(0.436)\end{array}$ & $\begin{array}{r}0.083 \\
(0.443)\end{array}$ & $\begin{array}{r}0.440 * * \\
(0.033)\end{array}$ & $\begin{array}{r}0.413 * * \\
(0.039)\end{array}$ & $\begin{array}{r}0.432 * * \\
(0.042)\end{array}$ & $\begin{array}{r}1.405 * * \\
(0.021)\end{array}$ & $\begin{array}{r}1.376 * * \\
(0.017)\end{array}$ & $\begin{array}{r}1.402 * * \\
(0.024)\end{array}$ & $\begin{array}{r}1.994 * * \\
(0.044)\end{array}$ & $\begin{array}{r}1.957 * * \\
(0.039)\end{array}$ & $\begin{array}{r}1.998 * * \\
(0.047)\end{array}$ \\
\hline CEOGENDER & $\begin{array}{r}-0.062 \\
(0.122)\end{array}$ & $\begin{array}{r}-0.061 \\
(0.104)\end{array}$ & $\begin{array}{r}-0.058 \\
(0.136)\end{array}$ & $\begin{array}{r}-0.006 \\
(0.743)\end{array}$ & $\begin{array}{r}-0.009 \\
(0.638)\end{array}$ & $\begin{array}{r}-0.011 \\
(0.578)\end{array}$ & $\begin{array}{r}-0.161 * * \\
(0.036)\end{array}$ & $\begin{array}{r}-0.161 * * \\
(0.033)\end{array}$ & $\begin{array}{r}-0.159 * * \\
(0.041)\end{array}$ & $\begin{array}{r}-0.218 * \\
(0.058)\end{array}$ & $\begin{array}{r}-0.227 * * \\
(0.047)\end{array}$ & $\begin{array}{r}-0.213 * \\
(0.061)\end{array}$ \\
\hline $\begin{array}{l}\text { Observations } \\
\text { R-squared }\end{array}$ & $\begin{array}{r}685 \\
0.082\end{array}$ & $\begin{array}{r}685 \\
0.087\end{array}$ & $\begin{array}{r}685 \\
0.080\end{array}$ & $\begin{array}{r}709 \\
0.112\end{array}$ & $\begin{array}{r}709 \\
0.119\end{array}$ & $\begin{array}{r}709 \\
0.113\end{array}$ & $\begin{array}{r}680 \\
0.167\end{array}$ & $\begin{array}{r}680 \\
0.173\end{array}$ & $\begin{array}{r}680 \\
0.168\end{array}$ & $\begin{array}{r}694 \\
0.143\end{array}$ & $\begin{array}{r}694 \\
0.151\end{array}$ & $\begin{array}{r}694 \\
0.144\end{array}$ \\
\hline
\end{tabular}


TABLE 8

Earnings Response Coefficients

This table reports the OLS regression results of cumulative abnormal returns (CARs) on standardized unexpected earnings (SUEs) for honesty scores above/below median. Variable definitions are provided in Appendix A. $* * *, * *$, and $*$ denote statistical significance at $1 \%, 5 \%$, and $10 \%$ levels, respectively.

\begin{tabular}{|l|c|c|c|}
\hline \multirow{2}{*}{ VARIABLE } & CFO & CEO & CFO/CEO \\
\cline { 2 - 4 } & HONESTY & HONESTY & HONESTY \\
\hline SUE* $<$ MEDIAN & $0.003^{*}$ & $0.007^{* * *}$ & $0.004^{* *}$ \\
HONESTY & $(0.062)$ & $(0.000)$ & $(0.040)$ \\
\hline SUE*>=MEDIAN & $0.008^{* * *}$ & $0.003^{*}$ & $0.008^{* * *}$ \\
HONESTY & $(0.000)$ & $(0.065)$ & $(0.000)$ \\
\hline LOSS & $-0.019^{* * *}$ & $-0.020^{* * *}$ & $-0.020^{* * *}$ \\
& $(0.000)$ & $(0.000)$ & $(0.000)$ \\
\hline SIZE & 0.001 & 0.001 & 0.001 \\
& $(0.517)$ & $(0.549)$ & $(0.586)$ \\
\hline MTB & 0.002 & 0.002 & 0.002 \\
& $(0.214)$ & $(0.127)$ & $(0.205)$ \\
\hline Observations & 3,077 & 3,077 & 3,077 \\
\hline R-squared & $7.6 \%$ & $7.4 \%$ & $7.4 \%$ \\
\hline
\end{tabular}

